\title{
ISSN 2410-3586
}

\section{УЧЕНЫЙ \\ XXI BEKA \\ научный журнал}

$$
\begin{aligned}
& 11-2 \\
& 2019
\end{aligned}
$$




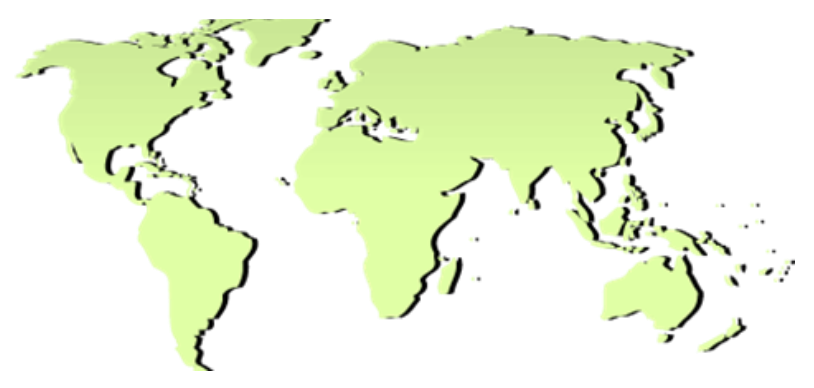

\section{УЧЕНЫЙ ХXI ВЕКА}

международный научный журнал

№ 11-2 (58), ноябрь 2019 г.

Редакционная коллегия

А.В Бурков, д-р. экон. наук, доцент (Россия), главный редактор.

Е.А. Мурзина, канд. экон. наук, доцент (Россия), технический редактор

В.В. Носов, д-р. экон. наук, профессор (Россия),

О.Н. Кондратьева, д-р. фил. наук, доцент (Россия),

Т.С. Воропаева, канд. психол. наук, доцент (Украина),

К.В. Дядюн, канд. юрид. наук, доцент (Россия),

У.Д. Кадыров, канд. психол. наук, доцент (Узбекистан),

Т.В. Ялялиева, канд. экон. наук, доцент (Россия),

Н.В. Щербакова, канд. экон. наук, доцент (Россия),

Учредитель:

Scope Academic House LTD

Издатель:

Scope Academic House LTD

Координатор в России ООО «Коллоквиум»

Адрес редакции:

Office 1 Velocity tower

10 st. Mary's gate

Sheffield, S Yorkshire, United Kingdom, S1 4LR
Редакторы:

E. А. Мурзина (Россия)

Bred Foreston (Великобритания)

Дизайн обложки: Студия PROekT

Распространяется бесплатно.

Полное или частичное воспроизведение материалов, содержащихся в настоящем издании, допускается только с письменного разрешения редакции. Мнение редакции может не совпадать с мнением авторов.

Статьи публикуются в авторской редакции.

uch21vek@gmail.com

Сетевое распространение на http: // www.uch21vek.com

(C) Scope Academic House LTD 


\section{СОДЕРЖАНИЕ НОМЕРА}

Технические науки

Воздействии отходов горючих продукций на окружающую среду

И.Т. Улуханов, К.М. Умаров

Филологические науки

Язык - это великое искусство

Т.А. Нишанова

Similarities between English and German

K.M. Begmatov

Педагогические науки

The impact of bilingualism on the personal development of children

M. Bobojonova

Educational and edifying roles of the physics extracurricular activities

I.O. Zokhidov, Ja.Kh. Mukhiddinov

Пути внедрения дистанционного образования в преподавание дисциплин в области наземных транспортных систем

Д.Д. Инамов, Б.М. Хайдаров

Особенности организации труда учителя

Д.Х. Эргашева, 3.О. Рахматуллаева

Педагогическое мастерство учителя

У.Ф. Туманов

Особенности учебной деятельности и формирование личности в младшем школьном возрасте

С.Ю. Акбаров

Pedagogical mechanisms of formation of creative and social activity in students

Ja.R. Mukhitdinova, M.M. Xayitmirzayeva

Methods of application of new pedagogical technologies in physical education classes

U.L. Qo'chqorov

The mechanism of language acquisition of gaming technologies in english lessons

B. Matkarimova

On the role of thinking in language learning

D.M. Khamrakulova

Психологические науки

Мотивация деликвентного поведения подростков

Д.Х. Эргашева, Д.М. Муминова

Значение игр в устранении речевых недостатков у детей

Д.А. Хомидова

Юридические науки и государственное управление

Участие республики Узбекистан в международной программе

Х.М. Акрамов

Роль государственной молодежной политики в развитии общества

Д.А. Рахимбоева

Информация для авторов 
Технические науки

УдК 62

\section{ВОЗДЕЙСТВИИ ОТХОДОВ ГОРЮЧИХ ПРОДУКЦИЙ НА ОКРУЖАЮЩУЮ СРЕДУ}

И.Т. Улуханов ${ }^{1}$, К.М. Умаров²

\section{Аннотация}

В данной работе рассмотрен вопрос образования вторичных продуктов при использовании различного топлива в современных энергетических и технологических установках, состав топлива и основные факторы, влияющие на окружающую среду, а также, рассмотрены вопросы возникновения экологических проблем и основные требования при топке энергетических ресурсов.

Ключевые слова: вторичный продукт, образование, энергетика, установка.

Zamonaviy texnologik qurilmalardan foydalanish ma'lum bir cheklanishni, yani, qo'yilgan talablarga rioya qilishni taqazo etadi. Jjumladan, turmushimizda foydalanilayotgan eng zamonaviy issiqlik qurilmalardagi termodinamik jarayonlarni o'ta murakkab kechishi ko'plab faktorlarni hisobga olishni, amalda foydalanish qoidalarga qat'iy rioya qilishni talab qiladi. Bu esa hozirgi davrda energetika zahiralarini ishlatish qurilmalaridan unumli foydalana bilish, mavjud ekologik muammolar echimini topish, uni yomonlashib borayotgan ayni chog'da ekologik jihatdan toza bo'lgan texnologiyalarni qo'llash hamda energetik inqirozga chek qo'yish kabii muammolarni hal qilishga yordam beradi.

Shu turdagi texnologik masalalar va ular bilan bog'liq muammolarni optimal usulda yechimini topish hozirgi zamon ishlab chiqarishining dolzarb muammolaridan biridir. 5111000-Kasb ta'limi (5310600 - Yerusti transport tizimlari va ularning ekspluatatsiyasi (avtomobil transporti)) bakalavriat yo'nalishida taxsil olayotgan talabalarning malaka talablarida ularga ana shunday muammolar echimini doimo izlash va amalda qo'llay olish mas'uliyati yuklangan.

Aytib o'tilganidek, texnologik qurilmalar, jumladan, issiqlik mashinalari va qurilmalaridan chiqariladigan ikkilamchi mahsulotlar atmosfera basseynida ekologik muammolarni paydo bo'lishida birlamchi sababchilaridan hisoblanadi. Insoniyat oldidagi eng dolzarb masalalaridan biri atrof muhit muhofazasidir. Ma'lumki, ekologiya - organizmlarni o`zaro va atrof muhit bilan o`zaro aloqasi haqidagi fan hisoblanadi.

Yoqilg'i resurslaridan energetic qurilmalarda foydalanilganda hosil bo'ladigan chiqindi mahsulotlarning atrof-muhitga ta'siri quyidagi salbiy oqibatlarda namoyon bo'ladi [1-2]:

-atmosfera havosining, undagi kimyoviy tarkibning o'zgarishida;

- suv va er qobig'ini chiqindi mahsulotlari bilan ifloslanishida;

- yoqilg'i mahsulotlari ta'sirida kishilarning zaharlanishida;

- texnologik qurilmalarda ishlab chiqilgan zaharli tarkibli mahsulotlar bilan havoning keskin ifloslantirilishida;

- ekomuvozanatning tiklanish murakkabligida.

Deyarli kam miqdorda bo'lsa ham organizmlarga kirganda uning organizmining normal hayot faoliyati havfsizligi jarayonini buzilishi, hattoki zaharlanishi mahsulotni toksikliligi (zaharliligi) tushuniladi.

1Улуханов Иброхим Тухтахужаевич - кандидат физико-математических наук, доцент, Наманганский государственный университет, Узбекистан.

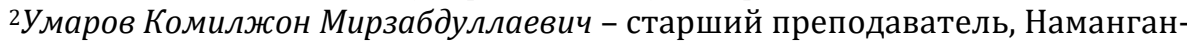
ский государственный университет, Узбекистан. 
Agregat holatidan qat'iy nazar har qanday yoqilg'ni texnologik qurilmada ataylab yoqiladi va zaruriy issiqlik energiya olinadi. Tabiiyki, manbalarda keltirilgan va amalda iste'mol qilib kelinayotgan barcha turdagi yoqilg'ilarning tarkibini yonuvchi va yonmaydigan (ballast) elementlardan:

$\left(\mathrm{C}^{\mathrm{daf}}+\mathrm{H}^{\mathrm{daf}}+\mathrm{O}^{\mathrm{daf}}+\mathrm{N}^{\mathrm{daf}}+\mathrm{S}^{\mathrm{daf}}+\mathrm{A}^{\mathrm{i}}+\mathrm{W}^{\mathrm{i}}=100 \%\right)$

tashkil topgan[1].

Tarkibga kiruvchi yonuvchi hisoblangan elementlar yonishi natijasida murakkab kimyoviy birikmalar, yani yuqorida taakidlab o'tilganidek tirik organizmlar hayotiga salbiy ta'sir ko'rsatuvchi zaharli gazlar ham hosil bo'ladi. Jarayonda qatnashuvchi tarkibidagi yonmaydigan elementlar $\mathrm{kul}\left(\mathrm{A}^{\mathrm{i}}-\mathrm{SiO}_{2}, \mathrm{AL}_{2} \mathrm{O}_{3}, \mathrm{FeO}, \mathrm{CaO}, \mathrm{MgO}, \mathrm{K}_{2} \mathrm{O}\right)$ va namlik $\left(\mathrm{W}^{\mathrm{i}}-\mathrm{H}_{2} \mathrm{O}\right)$ ni tashkil qiladi. Yoqilg'i mahsulotining asosiy yonuvchi elementlari $\mathrm{C}$ va $\mathrm{H}$ hisoblanadi.

Amalda ishlatiladigan yonish mahsuloti sifatiga baho berish tartibi uning ishchi, quruq, yonuvchi va organik massalarini tashkil qiluvchi elementlarning miqdorlari (\%) ehtiborga olish bilan bog'liq. Bundan tashqari belgilangan talablarga javob beruvchi yonilg'i sifatida ishlatiladigan organic moddalar tirik organizmlar hamda atrof muhit uchun zararsiz bo'lishi shart. Yonilg'I yonganda hosil bo'lgan yonish mahsuloti zaharliligi uch guruh: elemetli, guruhiy va fraksion tarkibga bo'linadi. Ishlab chiqarilgan zaharli gazning zaharliligini - ishlagan gazda zararli mahsulot konsentratsiyasini kamaytirishni bir- biridan farqlanuvchi faol va passiv usullari mavjud[3-4].

Faol usulning qo'llanilishi qurilmaning ish jarayonida zaharli mahsulotning generatsiyalanishini kamaytirish va yonish jarayonida shunday mahsulotni kam hosil qiluvchi yonilg idan foydalanishga asoslangan.

Passiv usulda esa texnik qurilmalarning chiqarish tizimida hosil bo'ladigan zaharli mahsulotlarni neytrallashga asoslangan.

Yonish yarayoni havfi yoqilg ilarning alangalanish va portlanuvcganligi havfi bilan aniqlanadi hamda miqdoriy jihatdagi quyidagi ko`rsatkichlari bilan harakterlanadi:

- bug larni alangalanish temperaturasi;

- o`t olishi va o`z-o`zidan alangalanishi;

- shu bilan birga yonilg'i hamda havo aralashmasining yuqori va quyi konsentratsiya chegarasi.

$\mathrm{Bu}$ chegaralarda aralashma portlovchan bo`ladi. SHu ko`rsatkichlar doimiy kattalikka ega bo'Imay, issiqlik almashinishi va o'tkazish tezligi, yondirish manbasidan keltirilgan energiya va boshqa faktorlarga ham bog`liq.

Tez alangalanuvchi yonilgilarning yonishi albatta portlash bilan bo'ladi. Neftdan olingan mahsulotlarning biri (dizel)ning ikkinchisi(benzin)ga nisbatan portlanuvchanligi birmuncha kichik hisoblanadi.

Termodinamika fanida texnologik qurilmalar, yoqilg'ilar, issiqlik olish usullari, yoqilg'ilardan foydalanish, texnologik jarayonlarda sodir bo'ladigan muammolar echimini topish, erishilgan yutuqlarga asoslanib issiqlik qurilmalarida yoqilg'ilarni yoqish va bu turdagi mahsulotlarning atrof muhit hamda tirik organizmga ko'rsatadigan salbiy ta'siri, qanday zaruriy chora-tadbirlarni amalga oshirish, amal qilish kerakligini masalalariga ilmiy asoslarga tayangan holda jiddiy e'tibor beriladi.

Yerusti transport tizimlari va ularning ekspluatatsiyasi bo'yicha mutaxassislik yo'nalishida tahsil olayotgan talabalar o'zlarining kelajak faoliyatlarida bunday muammoli masalalarga ko'plab duch keladilar. Mutaxassis sifatida bu masalalarni nazariy va amaliy bilim hamda tajribalarga tayangan holdagina yecha olishi va oqibatda muhofaza masalalariga oid har qanday muammoli vaziyatga samarali echim topa bilishlari lozim deb hisoblaymiz.

Texnologik qurilmalar turi zamonaviy bo'lishiga qaramay bu muammolar har doimo actual bo'lib qoladi hamda samarali echimga muxtoj.

Demak, texnologik qurilmalarda yoqilg'ilarning yonishi jarayonlarida sodir bo'ladigan muammolar yechimini topishda yoqilg'ilarni yoqishi va hosil bo'lgan yonish mahsulotlarini atrof muhitga salbiy ta'sirini minimallashtirish, zararli chiqindilar hosil bo'lishini oldini olishning samarali yo'llarini toppish, salbiy oqibatlarni kamaytirishga qo'yiladigan majburiy talablarga qat'iy amal qilish malakasiga ega bo'lishni taqazo etadi. Bunga esa termodinamika fanida o'rgatiladigan ishlab chiqarish hamda iqtisodiyotning, xalq xo'jaligining barcha tarmoqlarida keng foydalaniladigan 
qurilmalardan samarali foydalanish, qurilmalarni mukammallashtirish yo'llarini topish, ularga oid to'plangan nazariy va amaliy bilimlar hamda tajribalarning ilmiy natijalariga tayangan holda real tadbiq eta bilish orqaligina erishiladi.

Foydalanilgan adabiyotlar:

1. Теплотехника. Под.ред.А.П.Баскакова и др. Москва. Энергоиздат. 1982.

2. I.T.Uluhanov Termodinamika fanidan laboratoriya ishlari. Uslubiy qo'llanma. Namangan. 2017.

3. Теплотехника. Под ред. В.И.Крутова, Москва. Машиностроение. 1986. -426 с.

4. Теплотехнический справочник. В 2-х томах. Под ред. В.Н.Юренева., П.Д.Лебедева, Москва. Энергия. 1975.

(C) И.Т. Улуханов, К.М. Умаров, 2019. 
Филологические науки

Удк 82

ЯЗЫК - ЭТО ВЕЛИКОЕ ИСКУССТВО

Т.А. Нишанова ${ }^{1}$

Аннотация

В этой статье говорится о сущности и величия национального, в частности, узбекского языка. Язык - зеркало развития всего народа и общества в котором он созидает, культурное наследие народа. Как говорил в своё время Великий Конфуций,- “Искусство языка в его понимании”.

Ключевые слова: язык, зеркало, развитие,общество, наследие, искусство.

Тил инсонларнинг биргалашиб мехнат қилишларида, бошқалар билан алоқада бўлиш зарурлигидан пайдо бўлган.Тилнинг умри уни яратган халқнинг умридан узоқ бўлади, хизмат доираси кенг, хажми ўлчовсиз. У халқнинг маданий мероси, тараққиёт кўзгусидир. Миллат борки, унинг тили "жонли" хисобланади. Мамлакат тарихи ва маданияти, халқнинг оғзаки ижоди, кундалик хаёти, тарихий обидалар, ёдгорликлар, асарлар, миллий қадриятлар ўз ифодасини она тилида топади.

Буюк хитойлик олим Конфуций тил хақида “тилнинг санъати уни тушунишдадир" деган эди. Дархақиқат,тил табиат мўжизасидир."Жонли” тил сохибларнинг дунёсида яшайди. Боғбон боғини парваришлагани каби, хар бир миллат ўз она тилини химоялаши, ардоқлаши зарур. Республикамиз мустақил бўлгач, ўзбек тилига давлат тили мақоми берилди. Халқимизда шундай нақл бор “Тилга эътибор -элга эътибор”. Ўзбекистон Президенти Шавкат Миромонович Мирзиёевнинг давлат тилига бўлган эътибори, хурмати халқимиз хаётида катта бурилиш ясади. Айниқса, Президентимизнинг китобхонлик маданиятини ривожлантириши билан бирга нафақат тилга эътибор, балки элга бўлган эхтиромни юксалтирди.Шу билан бирга, авлод-аждодларимизнинг бизга қолдирган маданий мерос ва миллий қадриятларни ўрганиш ва тиклаш имконига эга бўлишимизни, халқимизни маънавий жихатдан сезиларли даражада ўсишини эътироф этиш жоиздир.

Тилнинг ранг-баранглиги, гўзаллиги, завқлилиги фақат тил сохибларгагина аёндир. Бизга етиб келган маданий меросдан кифояланмасдан, тилимизни доимо ривожлантириш, ўстириш даркор, бўлмаса у қуриган ер каби қақшаб кетади. Дунёдаги хар бир инсон ўз тилининг сохиби ва мухофазачиси хисобланади. У қанчалик чиройли гапирса, шунчалик тилга, жамиятга фойдалидир. Айни пайтда уни атрофдагиларнинг тушуниши осонлашади.

Немис миллатига мансуб бўлган машхур инсонлардан бири тил хақида қуйидаги фикрни билдирган : “Тилга эхтиёткорона муносабатда бўлишимиз керак, уни буюк санъат асари даражасигача кўтариш мумкин. Масалан: немис адабиётининг буюк намоёндалари Шиллер ва Гётеларнинг қолдирган дурдона асарлари бунинг исботидир, лекин тилнинг асосий вазифаси мулоқот воситаси эканлигидир."

Немис саркардаси Буюк Карл IVчи она тилини - халқ тили деб тан олган. Унинг фикрича, давлатни бошқаришда она тилининг ахамияти катта. Қалқ билан хамнафас бўлиб яшаш, у билан миллий тилда хамкорлик қилиш, мамлакатнинг тараққиётига салмоқли хисса қўшиш демакдир, дейди у.

“Биз мамлакатда эмас, балки тил дунёсида яшаймиз,” деган эди ўз даврида файласуф Эмил Циоран. Мамлакат бу - халқ, тил - халқ кўзгуси. Халқимизда шундай гап бор:“Бир иқлимга мослашган дарахт ёки ўсимликни бошқа юртда

${ }^{1}$ Нишанова Турсуной Абдивахидовна - старший преподаватель, Наманганский государственный университет, Узбекистан. 
ўсмагани каби, халқни, уни тилини ўзга юртга кўчириб бўлмайди." Бу табиат, хаёт қонуни. Тилни кириб келган ёт сўзлардан мухофаза қилиш керак. Улар фикрни чиройли ва равшан ифода этишимизга халақит беради. Масалан, хозирда немис тилига 600 тадан зиёд инглизча сўз кириб келган. Айрим немис сиёсатшунослари, иқтисодчилари, буни замон талаби, замонавийлик белгиси деб қарашади. Бундан ташқари, Германиянинг тараққиётига катта хисса қўшади деган фикрни илгари сурадилар. Нуфузли симпозиумларда кўпчилик немис нотиқларнинг севимли тили инглиз тили бўлиб бормоқда. Бу ачинарли хол албатта. Айнан шу каби инсонлар она тилида фақат оилада гаплашиш керак каби фикрга таянадилар. Лекин гуруч курмаксиз бўлмаганидек, бундай холатни кўплаб тилларда кузатиш мумкин. Яна бир мисол, французларнинг она тилига бўлган фидоийлигига қойил қолса арзийди. Гап шундаки, француз тилига кириб келган хар бир сўзга давлат аралашуви ёрдамида очиқдан-очиқ "уруш" эълон қилинади.Бу французларнинг миллий тилига бўлган чексиз мухаббати, садоқати, қадрини кўтариш ифодаси деб тушуниш лозим.

Она тилига бўлган мехр-мухаббатни оиладан бошламоқ керак. Айниқса, ота-онадан кейин турган ўқитувчилар бунга масъулдирлар. Биринчидан, ўқувчиларда чиройли гапириш ва фикрлаш кўникмаларини ривожлантириш ва одатий холга айлантиришда ёрдам бериш. Иккинчидан, она тили санъат асари эканлиги, уни янада сайқаланиб боришига, ривожланишига хисса қўшиш бурчимиз эканлигини тушунтириш лозим.

Хулоса шуки, ёш авлодда миллий тилга бўлган мехр-мухаббатни, садоқат, ғурур каби туйғуларни ривожлантириш биз катталарнинг вазифасига киради. Ёшларимиз Ватанни, она тилини муқаддас билиши ва бу уларнинг асосий фарзандлик бурчи эканлигини унутмасликлари лозим.

Фойдаланилган адабиётлар:

1. С. Сайдалиев. Чет тил методикасидан очерклар, Наманган, 2004 й.

2. Ф.А. Габдулхаков Тил таълими жараёнида тил соқиби тайёрлаш муаммолари, Филология масалалари, Наманган, 2007 й. 
UDC 82

\section{SIMILARITIES BETWEEN ENGLISH AND GERMAN}

K.M. Begmatov ${ }^{1}$

\section{Abstract}

The article describes the importance of studying English and German for business and everyday communication; the similarities of languages from the point of view of their origin, as well as lexical, phonological, morphological and grammatical correspondences of English and German languages, contributing to the mutual influence of languages on each other, which facilitates their understanding and study; specific examples of these similarities are also provided.

Key words: English; German; Indo-European language family; lexical, phonological, morphological, grammatical similarities of languages.

Language arose simultaneously with the emergence of social relations in the process of joint work of primitive people, and since its inception, the development of the language has been continuously associated with the development of society. It is known that most people in the modern world speak more than one language, that is, they are bilingual or multilingual. The cultural processes taking place in the world contribute to the study of several foreign languages, as this facilitates business communication, cultural exchange and facilitates the implementation of contacts.

The international language of communication is English, as it occupies the second place in the world in the number of people speaking it (about 1 billion). Modern trends in social development in Europe contribute to the growing role of the German language, which is one of the ten studied languages of the world. According to statistics, every year 15-18 million people begin to study German.

German and English are two similar languages. Most of the similarities between German and English are due to the fact that a significant part of the vocabulary has common roots. Words appear differently in these languages, but in some cases the difference in spelling and pronunciation is not large, and you can easily understand some words and phrases without knowing one of these languages.

For example, "unter dem Wasser" is easily recognized as "under the water", and "Ich habe es getan" as "I have done it."

English and German belong to the Indo-European language family. Both of these languages belong to the West Germanic branch of languages. However, they are completely different. English and its ancestor Old English are members of the Anglo-Frisian group. While the German language belongs to the proto-Germanic group.

German is divided into high and low German. While high German is the official language of Germany, Low German is seen as a dialect still spoken in the northern part of Germany. Both are important for the history of the language because they spawned the languages that are still spoken today.

In this article, we will analyze the similarities between modern high German and modern English.

English and German are different languages, but, nevertheless, they are not so dissimilar. In low German, the sentence "He swamm in dat deepe Water" can be easily understood as "He swam in the deep water". The version in high German sounds like: "Er schwamm in dem tiefen Wasser." This difference stems from a shift in the consonants of high German5. The following table illustrates the differences between Old English and German and modern English and German:

${ }^{1}$ Бематов Кувончбек Мухторович - преподаватель немецкого языка, Самаркандский государственный институт иностранных языков, Узбекистан. 


\begin{tabular}{|c|c|c|c|c|}
\hline Old English & etan & slæpan & ic & scip \\
\hline Modern English & eat & sleep & I & ship \\
\hline Old Low German & etan & slapan & ik & scip \\
\hline Modern Low German & eten & slapen & ik & Schipp \\
\hline Old High German & e an & slafan & ih & scif \\
\hline Modern High German & essen & schlafen & ich & Schiff \\
\hline
\end{tabular}

Consider the similarities between English and German in terms of lexicology, phonology, morphology and grammar.

In modern English and German, the lexical similarities are obvious. They can be easily traced from the ancient forms of both languages, as in the following examples:

English man sing father

Old English man singan fœder

German mann singen vater

Old High German man singan fater.

German and English have many root words: Winter / winter, Haus / house, trinken / drink, etc.

In addition, the German alphabet contains 26 letters, as well as the English alphabet, plus the umlauts of the letters: ä, ö, ü and $ß$.

As for phonology, the sounds of English and German are very similar, as well as the stress and intonation. However, the sound "th" in the words this, thing, that does not exist in the German language, and many people have problems pronouncing such words. German words starting with "w" are pronounced as "v". This explains the incorrect pronunciation of English words like we, wine like ve and vine.

Consider the grammatical similarities of languages. There is a significant discrepancy between the tenses of the verbs used in English to convey a certain meaning and those used in Germany.

For example, German does not have long time forms, so phrases like I can't come now; I eat my dinner; or He is riding his bike to school every day. Another example of inconsistency is the use of the present simple time in German, while the English language uses the future with the form will. This leads to errors such as: I tell him when I see him.

Another common problem for Germans is choosing the right time to talk about the past. Spoken German usually uses the present perfect tense when talking about past events: Dann habe ich ein Bier getrunken. The same time is used in English, but it is translated incorrectly: Then I have drunk a beer.

German is inflected. This means that most parts of speech change according to their function in the sentence. In English, the word is largely unchanged.

German has three word order functions in a sentence that do not exist in English:

1. First, the main verb should be the second element in the sentence. This often requires inversion of the subject and the verb. For example: Manchmal komme ich mit dem Bus in die Schule. (Sometimes I come to school by bus.).

2. Secondly, the main verb should be the last element in the subordinate clause. For example: Sie fragte mich, weil ich zuviel Coffee getrunken habe. (I feel bad because I have drunk too much coffee.).

3. Third, past participles should be the last element in a sentence. For example: Ich habe ihn nicht gesehen. (I have not seen him.)

German does not cancel the case system. The English sentence: "An old woman gave an apple to a little girl" can be expressed in German in the following ways:

1. Eine alte Frau gab einem kleinen Mädchen einen Apfel.

2. Einem kleinen Mädchen gab eine alte Frau einen Apfel.

3. Einen Apfel gab eine alte Frau einem kleinen Mädchen.

4. Es gab eine Frau einem kleinen Mädchen einen Apfel.

There are also grammatical correspondences in the education of comparative and superlative degrees of comparison of adjectives in modern English and German.

To form a comparative comparison of adjectives and most adverbs in English and German, the -er suffix is added, for example: dick / dicker (thick / thicker), klein / kleiner (small / smaller).

For superlatives, the suffix -est is used in both languages, except that in German the word "e" is often dropped and the adjective is added: (der) dickste (the thickest), (das) kleinste (the smallest). The following table illustrates these similarities. 


\begin{tabular}{|c|c|}
\hline English & German \\
\hline thick, small & dick, klein \\
\hline thicker, smaller & dicker, kleiner \\
\hline thickest, the smallest & der dickste, das kleinste \\
\hline
\end{tabular}

Similarities apply to exceptions when degrees of comparison are not formed according to the rule. The following table shows some cases of the formation of degrees of comparison of such adjectives.

\begin{tabular}{|c|c|c|c|}
\hline English & German & English & German \\
\hline good & gut & much & viel \\
\hline better & besser & more & mehr \\
\hline best & $($ am) best(en) & most & am meisten \\
\hline
\end{tabular}

However, unlike English, German never uses "mehr (more)" with a different definition for making comparisons. In English, "more" is used to form a comparative degree in adjectives with two or more syllables: more beautiful, more intelligent, more interesting. And in German, the ending "-er" is always used for this purpose: schöner, intelligenter.

Grammatical correspondences can also be traced in the system of verbs. Similar are not only the ways of formation of the past tense, but also the formation of some irregular verbs. The following table allows you to track similarity data.

\begin{tabular}{|c|c|}
\hline English & German \\
\hline laugh - laughed & lachen - lachte \\
hate - hated & hassen - haste \\
love - loved & lieben - liebte \\
think - thought & denken - dachte \\
bring - brought & bringen - brachte \\
sing - sang - sung & singen - sang - gesungen \\
give - gave - given & geben - gab - gegeben \\
fall - fell - fallen & fallen - fiel - gefallen \\
\hline
\end{tabular}

The gradual interpenetration of cultures promotes the movement of lexical units from one language to another, as a result of which the vocabulary of each language is enriched.

References:

1. Baugh A. C., Cable T. A History of the English Language, 5th edition, Taylor \& Francis, London, 1993. - $464 \mathrm{p}$.

2. Bynon Theodora Historical Linguistics (Cambridge Textbooks in Linguistics), Cambridge, London, New York, Melbourne,1977. - 324 p.

3. Fromkin Viktoria A., Rodman Robert, Hyams Nina An Introduction to Language, publ. 2nd, New York, 2002. - $620 \mathrm{p}$.

4. Kastovsky Dieter Typological Differences between English and German Morphology and Their Causes in: Swan, Toril; Mørck, Endre; Westvik, Olaf Jansen (editors): Language change and language structure: older Germanic languages in a comparative perspective, Berlin, New York, 1994.

5. Kastovsky Dieter, Mettinger Arthur Language contact and the history of English, Frankfurt: Peter Lang, 2001.

6. Mitchell Bruce An Invitation to Old English and Anglo-Saxon England, Oxford, 5th edition, 1994. - $424 \mathrm{p}$.

7. Robinson Orrin W. Old English and its closest relatives: a survey of the earliest Germanic languages, London, 1993. - 320 p.

8. Scargill Mattew H. Notes on the development of the principal sounds of IndoEuropean through Proto-Germanic and West-Germanic into Old English, London 1951. - 42 p.

9. Sanders Willy: Sachsensprache, Hansesprache, Plattdeutsch: sprachgeschichtliche Grundzüge des Niederdeutschen, Göttingen, 1982.

10. Wasserzieher Ernst: Woher? Ableitendes Wörterbuch der deutschen Sprache, 16th edition, Bonn, 1963.

(C) K.M. Begmatov, 2019. 
Педагогические науки

UDC 378

\section{THE IMPACT OF BILINGUALISM ON THE PERSONAL} DEVELOPMENT OF CHILDREN

M. Bobojonova ${ }^{1}$

\section{Abstract}

The article discusses the psychological aspects of the problem of bilingualism of children, analyzes the advantages and disadvantages of bilingualism.

Key words: personal development, bilingualism, children's bilingualism.

"The borders of my language mean the borders of my world," once said the Austrian philosopher Ludwig Wittgenstein.

The modern era is not conceivable without continuous communication, and communication permeates all spheres of human activity. It is global. Who wins this communicative race? People who speak only one language, in other words "monolinguals", or those who are able to use two, they are called "bilinguals", or maybe the third - people who speak several foreign languages, they are proudly called "polyglots"? The answer is obvious: to know several languages is to be special, unlike others. Recently, in the world, especially in Europe, the number of bilingual children has been increasing. The problem of bilingualism in children is one of the central problems in modern linguistics [6, p.15].

So what is "bilingualism" in children: the key to the gates of success in a world where the borders of international contacts have long been erased, or is the danger threatening the full, harmonious development of the individual?

Bilingualism - lat. "Bi" - two, "lingua" - language; equally perfect command of two languages, the ability to equally use them in the necessary conditions of communication [2, p. 57]. However, in science to this day there are discussions about the interpretation of this term, namely, the criteria for "bilingual". I will cite the two most common ones: bilingual - this is one who can solve a certain communicative problem in a second language $[9$, p. 9-10], the second, more stringent, bilingual is the person who speaks and thinks the second language with the same degree of freedom [8, p.40]. The phenomenon of "bilingualism" is multifaceted: the classification of the concept has more than dozens of varieties of this phenomenon.

Consider children's bilingualism: in early childhood, language is acquired without volitional effort, and linguistic generalizations are formed internally, unconsciously [5]. Later, such assimilation becomes less effective, but does not disappear at all. For a bilingual child, there is a special connection between a concept and a word: there is one subject, and there are two words, while the child does not differentiate words by language. For him, they are only synonyms for one concept. However, with early bilingualism in a child aged 3 to 5 years, when there is a direct assimilation of the language system, each of the languages gradually acquires its own base.

When considering the problem of children's bilingualism, the question arises: does the second language have a negative effect on the native language? Unfortunately, in Uzbekistan this problem is not widely studied. However, many linguists are familiar with the controversy between "Mozart in the psychology of speech" by L. S. Vygotsky and researcher I. Epstein. In the course of this debate, the latter lagged behind the following: between language systems, each of which is associated with thought by associative connections, a contradiction arises, and resulting in a depletion of the native, a general mental retardation begins to develop. L.S. Vygotsky, relying on the results of his

${ }^{1}$ Бобожонова Муниса - студентка факультета английского языка, Самаркандский государственный институт иностранных языков, Узбекистан. 
own research, as well as on the works of the French linguist J. Ronge, claims the opposite: in his opinion, the interaction of different language systems not only does not inhibit mental development, but also contributes to development.

Turning to the pages of Russian history, we will see that many prominent cultural figures, as well as writers, have been speaking two or three languages since childhood, among them A.C. Pushkin, I.S. Turgenev, V.V. Nabokov.

Many researchers agree that children's bilingualism in the modern world is more an advantage than a disadvantage. Bilingualism has a positive effect on the development of all types of memory, cognitive and epistemological skills, analytical and logical thinking. Recent studies in this area indicate that bilingualism creates certain cognitive advantages [1, p.217] Moreover, children who speak two languages have a higher creative potential compared to their monolingual peers. It is known that the process of learning foreign languages positively affects the mental and emotional state of a child [10, p. 78]. Children who know two languages are more able to concentrate on information than their peers [4, p. 101]. They better analyze information, easily highlight the main thing. Bilingual children are more open to the world, they are not afraid of the international arena of communications [7, p. 103].

The conclusion is the following: bilingual children who speak another language besides their mother tongue are more tolerant; for them, the same edge is erased, which causes conflicts based on "their own" and "foreign".

These facts at the same time inspire the development of bilingualism, and are alarming, warning against the total substitution of direct personal and moral development of human by bilingualism.

In fairness, we note that without moral development and self-development of a person as an integrative creative process of becoming more spiritual, creating good, following as mandatory, universal values and principles of universality [3, p. 301], bilingualism cannot replace.

Summing up the above, I want to say: it is a mistake to believe that bilingualism is the cause of contradictions in the personality of the child. "Bilingualism" favors the comprehensive development of the child, who, in the process of simultaneously mastering several languages, learns not only himself, but also our multifaceted world. Moreover, since bilingualism arises where there is a dialogue of several cultures, it contributes to the enrichment of the individual with the cultural values of various peoples. At the same time, it must be understood that bilingualism is not a panacea for all problems, that is, it does not replace the full personal development of a person.

\section{References:}

1. Александрова Н.Ш. Раннее двуязычие и гипотеза созревания мозга. - СПб.: Питер, 2004. - $336 \mathrm{c}$.

2. Ахманова О.С. Словарь лингвистических терминов / О.С. Ахманова. - М : УРСС : Едиториал УРСС, 2004. - 571 c.

3. Брюхова Н.Г. Нравственное саморазвитие человека// European Social Science Journal (Европейский журнал социальных наук). 2015. № 7. С. 289-301.

4. Верещагин Е.М. Психологическая и методическая характеристика двуязычия (билингвизма) / Е.М. Верещагин. - М.: Изд-во МГУ, 2009.

5. Выготский Л.С. Собрание сочинений: В 6 т. - М., 1983. - Т. 3. - 368 с.

6. Залевская А.А., Медведева И.Л. Психолингвистические проблемы учебного двуязычия. - Тверь: Твер. гос. ун-т, 2002. - 194 с.

7. Львов М.Р. Основы теории речи: Учеб. пособие для студ. высш. пед. учеб. заведений. - М.: Издательский центр «Академия», 2002. - 248 с.

8. Нелюбин Л.Л. Толковый переводоведческий словарь PDF. - М.: Флинта: Наука, 2003. - $320 \mathrm{c}$.

9. Розенцвейг В.Ю. Языковые контакты. - Л.: Наука, 1972. С. 9-10.

10. Щерба Л.В. Языковая система и речевая деятельность. Л., 1974. С. 78-79.

(C) M. Bobojonova, 2019. 
UDC 378

\section{EDUCATIONAL AND EDIFYING ROLES OF THE PHYSICS EXTRACURRICULAR ACTIVITIES}

I.O. Zokhidov¹, Ja.Kh. Mukhiddinov²

\section{Abstract}

The article discusses about the importance of extracurricular activities in general and related with physics particularly. The authors suggest various types of physics extracurricular activities and express their own notion of their educational and edifying roles.

Key words: teaching physics; extracurricular activities; educational role of extracurricular activities; edifying role of extracurricular activities; physics circle.

The development of the society, education reforms carried out in Uzbekistan requires preparation of highly qualified specialists that meet world standards. This, in turn, determines necessity of improving contextual and methodological sides of education. [1].

As we know, the main goal of teaching physics is firstly, to scientifically explain fundamental laws of nature, to develop scientific outlooks and abilities of philosophical thinking of students, to create imaginations about physical processes that explain working principles of electronic equipments and machines, secondly to lay the foundation for continuity of education, development of gained knowledge, conducting scientific researches. [2]. Organizing and carrying out extracurricular activities are of high importance here. Extracurricular activities - there are various types, range widely.

Physics extracurricular activities at secondary schools include arrangement of physics parties, organizing circles, running scientific seminars of physics teachers, review of additional literature, performing independent observations and experiments, physics-related trips, learning creative works of physics scientists etc. Moreover, it is reasonable to hold contests as extracurricular activities such as "Race", "Physical miracles", "Intellect”, "Field of miracles", "Contest of wall papers", "Physics week" that are interesting for students, serve to develop their intellectual abilities and talents, to widen their knowledge base.

Each teacher of physics should be aware of fundamental bases of the subject, gain methods of pedagogy and psychology, demonstrate high professional competence, and have qualifications and skills to use in practice modern pedagogic and information technologies. In this case, extracurricular activities will show effect. [3].

The role of teacher in growing interest of learners to the subject and developing their creative initiatives is very significant. It is true that teachers do not have opportunity to introduce all scientific achievements to learners during the classes. Because information about such achievements are mostly gained not from coursebooks, but from mass media. Thus, teachers should motivate desire of learners participating extracurricular activities for learning bases of physics, support and develop their creativeness on the subject. To generate interest of learners in extracurricular activities, teachers should create processes of creative thinking using natural events as matter of discussion.

Physics extracurricular activities, similarly to curricular program, should perform the following educational and edifying functions:

1. All extracurricular activities should be directed towards broad increasing of knowledge of learners as today's age of progress of science and technology requires wide-knowledgeable in physics and technologies specialists to work in automated industry, with electronic equipment, to send spacecrafts, to develop production of semiconductors, to work in agriculture.

${ }^{1}$ Ibrokhimjon Zokhidov - candidate of Pedagogical Sciences, Associate Professor, Namangan State University, Uzbekistan.

${ }^{2}$ Mukhiddinov Jasurbek - teacher, Namangan State University, Uzbekistan. 
2. Extracurricular activities should increase interests of learners in acquisition of bases of the subject and provide them opportunity to gain necessary skills for that need for autonomous study. [4].

The main goals of extracurricular activities are to supply learners with extra knowledge, skills and capabilities and help them to deepen, widen and strengthen their knowledge in physics.

Organizing meetings with national scientists or holding discussions on their lives and scientific achievements in physics circles can be very effective as extracurricular activities. In such cases learners become aware that they live in the neighborhood of scientists who contribute significantly to the development of physics. This sparks their hopes and aims to learn more the subject. From this point, activities dedicated to such scientists that well-known national-wide and world-wide, but included to secondary school curriculum will support learners in gaining the secrets of the subject and develop their scientific outlooks.

We offer teachers to organize and hold meetings, evenings, parties dedicated to the lives and scientific achievements of scientists that live in the neighborhood with learners.

The above expressed notions show that the combined pedagogical process of education and edification provides a basis for organization of physics extracurricular activities and determines their context, forms and methods.

\section{References:}

1. Decree №50 of the Cabinet of Ministers of the Republic of Uzbekistan “On measures for further development of the system of out-of-school education" dated February 28, 2011

2. Mirzakhmedov B., G'ofurov N., Ibragimov B., Sagatova G. Fizika o'qitish metodikasi. Tashkent, "TDPU”, 2007.

3. Tarasov L.V. Sovremennaya fizika v sredney shkole -Moscow.: "Prosvetsheniye" 1990.

4. Yusupov A. Fizikadan sinfdan tashqari mashg'ulotlar Tashkent.: “O'qituvchi”, 1996

(C) I.O. Zokhidov, Ja.Kh. Mukhiddinov, 2019. 
удк 378

\title{
ПУТИ ВНЕДРЕНИЯ ДИСТАНЦИОННОГО ОБРАЗОВАНИЯ В ПРЕПОДАВАНИЕ ДИСЦИПЛИН В ОБЛАСТИ НАЗЕМНЫХ ТРАНСПОРТНЫХ СИСТЕМ
}

\author{
Д.Д. Инамов ${ }^{1}$ Б.М. Хайдаров²
}

Аннотация

В статье рассматривается развитие дистанционного образования в Республике Узбекистан, обзор методов организации дистанционного образования, состояние и проблемы системы дистанционного образования, модели дистанционного обучения и их типы.

Ключевые слова: система дистанционного обучения, модели дистанционного обучения, внешность, консорциум, франшиза, валидация, удаленная аудитория.

Ўзбекистон Президенти Шавкат Мирзиёев жойларда ижтимоийиқтисодий ислохотларнинг бориши, аввал белгиланган вазифаларнинг ижроси билан танишиш мақсадида 2018 йилнинг 19 январь куни Сурхондарё вилоятига ташрифи чоғида вилоятдаги олий таълим муассасаларини пойтахтда фаолият кўрсатаётган университетлар билан хамкорлигини кучайтириш, хусусан педагогик технологияларнинг замонавий усулларидан фойдаланишни ташкил қилиш вазифаларини юклаган эди.

Хозирги кунда жахон стандартларига тўла жавоб берадиган, юқори технологиялар асосида жихозланган ишлаб чиқариш корхона ва заводлар барпо этилмоқда. Ушбу заводларда талабаларнинг мутахассислиги бўйича кўникма ва малакаларини шакллантириш учун назарий билимларни амалиёт билан боғлашда дастурлаштирилган масофавий “Onlin” ўқитиш тизимларини қўллаш зарур. Бу эса таълим тизими билан ишлаб чиқаришни узвийлигини таъминлайди хамда ер усти транспорт тизимлари йўналишидаги "Транспорт воситалари деталларининг иш қобилиятини қайта тиклаш технологиялари" фанини ўқитиш жараёнида назарий ва амалий маълумотларни талабаларга тўлиқ етказишга эришилади.

Олий таълим муассасалари олдидаги долзарб муаммолардан бири, юқори компетентликка эга малакали мутахассисларни тайёрлаш хисобланади. Чунки, Республикамизнинг ривожи, равнақи ва истиқболи кўпроқ ушбу мутахассисларнинг махоратига хам боғлиқдир. Шунинг учун ўқитишнинг янги илғор, фаол усулларини қўллаш, юқори технология воситаларидан оқилона фойдаланиш мақсадга мувофиқдир.

Масофавий таълим тизими орқали кадрлар тайёрлаш сифатини ошириш, талабалар учун масофавий ўқитиш имкониятини яратиш, таълимнинг турли интерактив шаклларини бир-бирига яқинлаштиришга эришиш мумкин.

Жахон амалиётида бу каби муаммоларни хал қилиш учун ахбороткоммуникация технологияларини кенг қўллаш асосида электрон таълим (elearning) ва масофавий ўқитиш имкониятларидан фойдаланиб келинмоқда. Агар илгари баъзи университетлар электрон таълим ва масофавий ўқитишнинг алохида элементларини таклиф қилган бўлсалар, охирги 6-7 йил давомида оммавий равишда ОООК технологиялари ёрдамида тақдим этилмоқда. Оммавий очиқ онлайн курс (инглиз тилидан MOOC - Massive Open Online Course) масофавий таълим шаклларидан бири бўлиб, Интернет орқали эркин кириш ва электрон таълим технологияларидан фойдаланган холда интерактив қатнашиш имконини берувчи оммавий ўқув курсларидир. Ўкув курсининг анъанавий материаллари, жумладан, видео, ўқиш ва уй вазифаларига қўшимча тарзда

${ }^{1}$ Инамов Дилмирза Дедамирзаевич - д.ф.н. (PhD), Наманганский инженернотехнологический институт, Узбекистан.

${ }^{2}$ Хайдаров Бунёд Маликбоевич - преподаватель, Наманганский инженернотехнологический институт, Узбекистан. 
оммавий очиқ онлайн курслар талабаларга, ўқитувчилар ва ассистентлар жамоаларини яратиш ва қўллаб-қувватлашга ёрдам берадиган интерактив форумларида қатнашиш имконини беради.

Оммавий очиқ онлайн курслар 2008 йилда масофавий таълим сохасида пайдо бўлди, лекин 2012 йилда Coursera, Udacity ва Udemy каби лойихалар биринчи инвестицияларни жалб қилгандан кейин чиндан хам машхур бўлди. о0ОКнинг дастлабки веб-сайтлари (масалан, Udacity) асосан эркин фойдаланиш концепцияси (очиқ контент)ни тарғиб қилди. Кейинчалик сайтлар тўлиқ ёки қисман бепул таълим олиш имкониятини қолдириб, пулли контентга ўтишди. Баъзи платформаларда ўзларининг хусусий контентлари (таълим материаллари) мавжуд эмас, аммо улар дунёнинг етакчи университетлари билан келишган холда улардан контент олишади. Олинган ўқув материалларини ўқувчилар учун қулай, тизимли тартибда ўз платформаларида жойлаштиришади.

Мисол учун, энг машхур платформалардан бири Coursera дунёнинг 150 дан ортиқ етакчи олий ўқув юртлари билан хамкорлик қилади ва талабаларга жахоннинг етакчи олий ўқув юртларининг онлайн курсларини таклиф этади. Кўпгина талабаларга таълим олиш учун жуда қулай механизм бўлгани учун улар оммалашган ва талаб юқоридир.

Бугунги кунда Ўзбекистонда 84 та олий таълим муассасаси, жумладан 21 та университет, 35 та институт, 2 та академия ва уларнинг жойлардаги 15 та филиали хамда хорижий олий ўқув юртлари билан хамкорликда ташкил этилган 7 та олий таълим муассасаси (Буюк Британия, Италия, Сингапур, Жанубий Корея, Россия) фаолият юритмоқда. Олий ва ўрта махсус таълим вазирлигининг маълумотларига кўра, сўнгги йилларда Ўзбекистонда анъанавий олий таълимга бўлган талаб (абитуриентлар сони) ва таклиф (ОТМлар квотаси) ўртасида катта фарқ мавжуд.

ОООК томонидан тақдим этилаётган таълим сифатини таъминлашда LMS (learning management system - таълим бошқарув тизими) платформаси катта ахамият касб этади, чунки у ўқитувчининг талаба билан ишлаш самарадорлигини таъминлайди. Масофавий таълим ва 000Кни ташкил қилиш учун турли хил LMS платформалар мавжуд. ООOK учун LMS платформасини ишлаб чиқиш ёки муваффақиятли фойдаланиб келинаётган платформалардан фойдаланиш мумкин.

Хорижда масофавий таълимдан шахсий режа асосида уйдан туриб билим олиш, университет томонидан тайёрланган видеодарслардан фойдаланиш, ишлаб чиқаришдан ажралмаган холда таълим олиш, шунингдек бир вақтнинг ўзида қўшимча тарзда бошқа йўналишларда таълим олиш ва шахсий қизиқишлари бўйича салохиятини ошириш тажрибаси кенг татбиқ қилинмоқда. Юртимиз таълим муассасаларида жорий қилинаётган ахборот-коммуникация технологиялари инфратузилмаси хам келажакда бу каби имкониятлардан фойдаланишга хизмат қилади.

Фойдаланилган адабиётлар руйхзати:

1. 20.04.2017й. Пқ-2909-сон “2017 - 2021 йилларда Олий таълим тизимини комплекс ривожлантириш дастури

2. А.Парпиев, А.Марахимов, Р.Хамдамов, У.Бегимкулов, М.Бекмурадов, Н.Тайлоқов Электрон университет. Масофавий таълим технологиялари ЎзМЭ давлат илмий нашриёти. -Т.: 2008, 196 б.

3. Абдуқодиров, Абдуқаххор Абдувакилевич. Масофали ўқитиш назарияси ва амалиёти. монография / А. А. Абдукадиров, А. Х. Пардаев; ред. М.Содикова. - Т. Ўзбекистон Республикаси фанлар Академияси " ФАН,2009. -145 с

4. Ziyonet.uz

5. Talim.uz

6. webdastur.uz

(С) Д.Д. Инамов, Б.М. Хайдаров, 2019. 
ОСОБЕННОСТИ ОРГАНИЗАЦИИ ТРУДА УЧИТЕЛЯ

Д.Х. Эргашева ${ }^{1}$, 3.0. Рахматуллаева²

Анотация

В данной статье широко освещены особенности организации труда, требования и задачи учителя, а также о его обязанностях.

Ключевые слова: труд, требование, учитель, обязанность, развитие.

Davlat va jamiyat hayotini modernizatsiyalash jarayonlarining harakatga keltiruvchi kuchi, O'zbekistonning bugungi va istiqboldagi izchil taraqqiyotining bosh omili bo'lgan insonning ma'naviyatini va kasbiy salohiyatini yuksaltirishda o'qituvchilarning tajribasi va mahoratini yanada takomillashtirish muhim ahamiyatga ega. O'qituvchi bugungi kunda ta'lim va tarbiya berayotgan shogirdlarining kamoloti bilan mamlakatimiz kelajagiga ulkan poydevor qo'yadi.

Shu o'rinda Prezidentimiz SHavkat Mirziyoyevning quyidagi so'zlari bunga misol bo'la oladi. "Yoshlarimizning mustaqil fikirlaydigan, yuksak intellektual va ma'naviy salohiyatga ega bo'lib, dunyo miqiyosida o'z tengdoshlariga hech qaysi sohada bo'sh kelmaydigan insonlar bo'lib kamol topishi, baxtli bo'lishi uchun davlatimizva jamiyatning bor kuch va imkoniyatlarini safarbar etamiz". Shunday ekan demokratik huquqiy jamiyat qurish jarayonida o'qituvchining o'rni, vazifalari yosh avlodni tarbiyalash ishiga javobgarligi muhim ahamiyatga ega. Olib borilayotgan islohotlarning ijobiy natijalar berishini yetuk va malakali mutaxassislar ta'minlaydi. Ularni voyaga yetkazish, ta'lim-tarbiya berish, o'qituvchiga yuklatilgan talablarning kun sayin ortib borishi, ularni hal etish vazifasi o'qituvchi mehnatini ilmiy asosda to'g'ri tashkil etilishiga bog'liq.

Hozirgi zamon o'qituvchisi o'z pedagogik mehnati jarayonida qator ta'limtarbiyaviy vazifalarni bajaradi. U avvalo ta'lim muassasalari o'quv jarayonining asosiy tashkilotchisidir. O'qituvchi ta'lim-tarbiya jarayonida hamda darsdan tashqari faoliyatda o'quvchilarning porloq kelajagi uchun javobgar shaxsdir. Ushbu ulkan mas'uliyat ijobiy natijalar berishi uchun o'qituvchi, avvalo, o'zining pedagogik mahoratiga tayanadi. Pedagogik mahorat shunday bir malakalar yig'indisidirki, uning natijasi o'qituvchi mehnatida va o'quvchilar xulqi, odobi, tarbiyasida, kelajakda yetuk mutaxassis kadr bo'lib yetishishida o'z aksini topadi. O'qituvchi o'zining qizg'in mehnati jarayonida pedagogik mahoratning quyidagi komponentlarini ma'lum darajada o'zlashtirishi lozim:

- yoshlar psixologiyasiga oid bilimlarga ega bo'lishi;

- nutq madaniyatining barcha turlari va metodlarini bilishi;

- o'qituvchi qobiliyati (empatiya, perseptiv, didaktik, konstruktiv, kommunikativ anglash)ning mohiyatini anglashi;

- aktyorlik mahoratini (mimika, pantomimika, notiqlik san'ati) egallashi;

- o'z kayfiyatini (hissiy psixik holat) boshqara olishi;

- tarbiyalanuvchilar bilan muloqot va muomala madaniyatini o'zlashtirishi;

- pedagogik texnika uslublarini o'z o'rnida qo'llay olish san'atiga ega bo'lishi.

Ushbu pedagogik mahorat komponentlari mamlakatimizda olib borilayotgan islohotlar, ijtimoiy-iqtisodiy talablar mohiyatidan kelib chiqishi kerak. Milliy mafkura, dastur talablari, urf-odat va an'analar pedagogik mahorat asosida tashkil etiladigan o'qituvchi mehnatning asosiy mohiyatida o'z aksini topishi kerak.

O'qituvchi mehnatining muvaffaqiyati va samarasi uni ilmiy jihatdan puxta tashkil etishga, mehnatni oqilona uyushtirishga ta'sir etadigan shart-sharoitlarga va

1 Эргашева Дилором Хамидуллаевна - преподаватель кафедры педагогики и психологии, Наманганский государственный университет, Узбекистан.

${ }^{2}$ Рахматуллаева Замира Олимжоновна - преподаватель кафедры методики дошкольного образования, Наманганский государственный университет, Узбекистан. 
mehnatni amalga oshirish yo'llarini to'g'ri belgilashga bog'liq. O'qituvchi mehnati doimo ijodkorlik bilan amalga oshiriladi. Shuning uchun mehnatni amalga oshiruvchi o'qituvchi avvalo o'z mehnatini rejalashtirishda, o'zi puxta egallagan pedagogik mahoratiga va o'z ilmiga tayanishi lozim. Hozirgi zamon axborot kommunikatsion texnologiyalarining taraqqiyoti davrida o'qituvchi mehnatini ilmiy asosda tashkil qilish fan va texnika yutuqlarini o'qituvchi tomonidan qay darajada o'zlashtirilishiga ham bog'liq. Pedagogik faoliyat yosh avlodni hayotga, mehnatga tayyorlash uchun jamiyat oldida, davlat oldida javob beradigan, ta'lim-tarbiya berishda maxsus tayyorlangan o'qituvchilar mehnati faoliyatidir.

Bu maqsad va vazifalarning hal etilishi o'qituvchilar va tarbiyachilarni zamon bilan hamnafas bo'lishga, yoshlarni tarbiyalash dardi bilan yashash va kelajakni aniq ko'ra olishga o'rgatadi. Har bir o'qituvchi shaxsida mamlakatimizning dolzarb muammolarini, maqsad va vazifalarini vijdonan tasavvur qilib, aniq bajarib borishi uchun shijoat bilan o'z imkoniyati, bilimi, tajribalarini ishga solishga o'rgatadi hamda pedagogik faoliyatga ijodiy yondashish malakalariga ega bo'lishni tarbiyalaydi. Shunday qilib, pedagogik mahorat egasi bo'lish uchun o'qituvchi o'z o'quv predmetini davr talablari asosida bilishi pedagogik va psixologik bilimlarga ega bo'lishi, hamda insoniylik, izlanuvchanlik va fidoyilikni o'zida tarkib toptirishi lozim. I.P. Radchenko pedagogik mahoratni pedagogik san'atning bir qismi sifatida ta'riflab, shunday yozadi: «pedagogik mahorat deganda o'qituvchining pedagogik-psixologik bilimlarni, kasbiy malaka va ko'nikmalarni mukammal egallashi, o'z kasbiga qiziqishi, rivojlangan pedagogik fikrlashi va intuitsiyasi, hayotga axloqiy-estetik munosabatda bolishi, o'z fikr-mulohazasiga ishonchi va qat'iy irodasi tushuniladi».

Shuni alohida qayd etib o'tish zarurki, ijodiy faoliyat olib boruvchi o'qituvchi faqatgina bolalarni muvaffaqiyatli o'qitish va tarbiyalash, ilg'or o'qituvchilar ish tajribalarini o'rganish bilangina cheklanib qolmasdan, tadqiqotchilik ko'nikma va malakalariga ham egabo'lishi zarur. Kozirgi zamon o'qituvchisi fan va texnika taraqqiyolining eng so'nggi yutuqlaridan foydalanishi, o'z kasbiy faoliyatida yangi pedagogik texnologiyalarni unumli qo'llay olishi, muntazam ravishda psixologiya va tarbiya nazariyasini mukammal o'rganib, o’z kasbiy faoliyatini muttasil rivojlantirib borishini taqozo etiladi

\section{Фойдаланилган адабиётлар рўйхати:}

1. Sh.Mirziyoyev "Erkin va farovon demokratok, o'zbekiston davlatini birgalikda barpo etamiz "-Toshkent "O'zbekiston" -2016

2. Ishmatov Q. Pedagogik texnologiya. Namangan. NamMII. $2004 \mathrm{y}$.

3. Kamoldinov M, Vaxobjonov B, Innovatsion pedagogik texnologiya asoslari. T.: Talqin. $2010 \mathrm{y}$.

4. Ijtimoiy axborot ta'lim portali: www. Ziyonet. uz.

5. http://www.school.edu.ru - Umumta'lim portali (rus tilida).

(с) Д.Х. Эргашева, 3.0. Рахматуллаева, 2019. 


\section{Аннотация}

Основной целью педагога должно быть воспитание у учителя, обладающего педагогическими знаниями и навыками, гармонично развитого поколения, реализация системы непрерывного образования, наблюдение за детьми, внимательное отношение к ним, проведение подготовленного к уроку урока, повышение педагогического потенциала и развитие способностей.

Ключевые слова: человеческие и профессиональные требования к личности учителя, образование, педагогические навыки, опыт, способности, убеждения, идеология, культура, профессиональная подготовка.

Inson tarbiyasi har qachon ham murakkab vazifalardan biri bo'lib kelgan. Hatto jamiyat me'yordagi stabil rivojlanish bosqichida turgan vaqtda ham o'sib kelayotgan yosh avlod tarbiyasida turli muammolar paydo bo'ladi. Bugungi kun muammolari esa (ishsizlik, qonunbuzurlik, oilaviy ajrashishlar, noqonuniy dori vositaliri va hatto giyohvand moddalardan foydalanish, shahsiy va profisional maqsadning yo'qligi, diniy ekstremizm, terrorchilik va h.o) ta'lim-tarbiya jarayonini yanada murakkablashtirib yubormoqda. Ma'lumki, ta'lim-tarbiya deb atalgan murakkab jarayon sub'ektlaridan biri - bu o'qituvchi. Ho'sh, bugungi kun o'qituvchisi qanday bo'lishi kerak? Uning faoliyati maqsadi va vazifalari nimalardan iborat? Uning bilim saviyasi, salohiyati, mahorati va qobiliyatini o'stirish nimalarga bog'liq? Eng avvalo o'qituvchi shuni chuqur anglashi lozimki, u jamiyatning ishonchli vakili, zero, jamiyat unga o'zining eng qimmatli boyligi, umidi, ishonchi va kelajagi bo'lgan bolalarini topshiradi. Bu oliyjanob va murakkab kasb unga hayotini bag'ishlagan har bir kishidan doimiy ijod, izlanish, ulkan sahovatli qalb, bolalarga muhabbat, o'z kasbiga cheksiz sadoqatni talab etadi.

O'zbekiston Respublikasi birinchi prezidenti I.Karimov davlat va jamiyat qurilishi akademiyasining ochilishi marosimida so'zlagan nutqida: "Birovni o'qitadigan, tarbiya qiladigan inson avvalo o'zi har tomonlama barkamol bo'lmog'i shart". Bundan ko'rinib turibdiki zamon talablari shuki, professor va o'qituvchilar o'zlarida mavjud bo'lgan bilim va saviya bilan cheklanib qolmasdan, xorijiy mamlakatlar tajribasini qunt va sabot bilan o'rganib, mag'zini chaqib, undan keyin o'z talabalariga saboq berishlari zarurligini alohida ta'kidlaydi. Mustaqil O'zbekistonimizda uzluksiz ta'lim tizimini isloh qilinishi, yangi ta'lim standartlari asosida ta'lim va tarbiya jarayonini qayta tashkil etishga kirishilgan hozirgi kunda o' qituvchi faoliyatiga? uning pedagogik mahoratiga alohida e'tibor berilmoqda.

Mamlakatimizda kadrlar tayyorlash milliy dasturini bosqichma-bosqich muvaffaqiyatli amalga oshirish ko'p jihatdan o'qituvchi faoliyatiga, uning kasbiy nufuzini oshirishga bog'liqdir. Shunday ekan, sog'lom, har tomonlama barkamol avlodni etishtirish uzluksiz ta'lim tizimida mehnat qilayotgan pedagogning saviyasiga, tayyorgarligiga va fidoyiligiga, yosh avlodni o'qitish va tarbiyalash ishiga bo'lgan munosabatiga bog'liqdir. O'qituvchi jamiyatning ijtimoiy topshirig'ini bajaradi, shunday ekan, har tomonlama etuk mutaxassislarni tayyorlashda o'qituvchi muayyan ijtimoiy-siyosiy, pedagogik va shaxsiy talablarga javob berishi lozim. Shunday ekan, o'qituvchi mustaqillik g'oyasiga e'tiqodi, har tomonlama rivojlangan ilmiy tafakkuri, kasbiga tegishli ma'lumoti, ya'ni o'z fanining chuqur bilimdoni, pedagogik muloqot ustasi, pedagogikpsixologik va uslubiy bilim va malakalarni egallagan bo'lishi hamda turli pedagogik vaziyatlarni tezda sezishi, o'rganishi va baholay olishi. Pedagogik ta'sir ko'rsatishning eng maqbul usul va vositalarini tanlay olish qobiliyatiga ega bo'lishi lozim.

Pedagogik bilim va mahorat egasi bo'lgan o'qituvchi avval, Pedagogika fanining metodologik asoslarini, shaxs rivojlanishining qonuniyatlari va omillarini, kadrlar

${ }^{1}$ Туманов Уктамжон Фазлиддин угли - преподаватель кафедры педагогики и психологии, Наманганский государственный университет, Узбекистан. 
tayyorlash milliy dasturining mohiyati, maqsad va vazifalarini bilishi darkor. Ta'lim tizimida mehnat qilayotgan pedagoglarning ko'pchiligi ta'lim va tarbiya jarayonida pedagogik mahoratning zaruriyati va ahamiyatini chuqur anglamoqdalar.

Shu sababli ular o'z mahoratlarini uzluksiz oshira borishga, hozirgi kunning yuksak talablariga mos zamonaviy bilim va tajribalarni o'zlashtirishga, ijodiy mehnat qilishga intilmoqdalar. Ammo shuni ham e'tirof etishimiz kerakki, o'quv yurtlarida ayrim o'qituvchilar o'z pedagoglik mahoratlarini oshira borishning ahamiyatini yetarli darajada his qilmaydilar, ta'lim to'g'risidagi Qonun, Kadrlar tayyorlash milliy dasturi talablarini chuqurroq o'rganishga qiziqmaydilar, o'quv jarayonining ilmiyligiga, zamon talablariga mosligiga, turmush, amaliyot bilan bog'lanishiga yuzaki qaraydilar, o'qitilayotgan o'quv fanlarining ilmiy va g'oyaviy-tarbiyaviy birligini doimo esda tutmaydilar. $\mathrm{Bu}$ esa ular qo'lida ta'lim olayotgan o'quvchi, talabalarning bilim darajasi va saviyasining etarli emasligiga, o'quv dasturlarini o'zlashtirishdan orqada qolishlariga sabab bo'lmoqda.

Uzluksiz ta'lim tizimini amalga oshirish jarayonida yosh avlodni ko'ngildagidek o'qitish va tarbiyalash haqida gap borar ekan, bu g'oyat murakkab va ko'p qirrali vazifani faqat malakali pedagogik mahoratga ega bo'lgan o'qituvchi kadrlar bilan amalga oshirish mumkin. Shunday ekan, o'qituvchilik katta san'atdir. Bu san'atga u yoki bu pedagog osongina, o'z-o'zidan erisha olmaydi. Buning uchun o'qituvchilik kasbiga, ya'ni sog'lom avlodning chinakam murabbiy bo'lishga havasi, ishtiyoqi zo'r, zamon talablarini tez va chuqur tushunadigan, o'zining ilmiy, ijtimoiy-siyosiy saviyasini, pedagogik mahoratini izchillik bilan amalga oshira boruvchi, mustaqillik g'oyasi va mafkurasi bilan puxta qurollantirgan, haqiqiy vatanparvar va mehnatsevar kishilargina erisha oladilar.

Pedagogik mahorat tug'ma talant yoki nasldan-naslga o'tuvchi xususiyat emas, balki izlanish, ijodiy mehnat mahsulidir. Bu ko'p qirrali pedagogik faoliyat zaminida ijodiy mehnat yotadi. Shuning uchun ham pedagogik mahorat hamma o'qituvchilar uchun standart, ya'ni bir qolipdagi ish usuli emas, balki u har bir o'qituvchining o'z ustida ishlashi, ijodiy mehnati jarayonida tashkil topadi va rivojlanadi. Mahorat - biror ish, kasb uchun zarur yoki shu sohada orttirilgan ustalik, san`at.

Pedagogig mahorat - bu shunday yuksak va muntazam takomillashib boruvchi ta`lim va tarbiya san`atidirki, uni o`qituvchilik kasbiga rag`bati bo`lgan va bolalarni sevgan har bir o`qituvchi egallashi mumkin.

Shu o'rinda buyuk mutasavvuf olim Jaloliddin Rumiy haqidagi bir rivoyatni keltirib o'tishni lozim topdik. Rivoyat qilishlaricha, mavlona Rumiy shogirdlari oldida va'z aytib turgan vaqtida unga bir yosh tolib qaltis savol beradi: "Ustoz, Siz qaysidir bir yig'inda "men 72 mazhab bilan birman", degan ekansiz. Shu gap rostmi?", - deb so'raydi. (Ma'lumki, islom dinida ihtiloflar tufayli 6 ta firqa paydo bo'lib, ularning har biri yana 12 tadan firqalarga bo'linib, 72 ta mazhab vujudga kelgan edi. Shular ichida eng to'g'ri va mukammali suniylar mazhabi sanaladi. Lekin Rumiy ularning birortasini keskin qoralamaydi va rad etmaydi. Chunki Rumiyning fikricha, har bir mazhab ollohning yakka-yagonaligini rad etmagan holda o'z manfaatidan kelib chiqib, shunday farqlarga bo'linib ketganlar va shunday bo'lishi tabiiy hol). - Ha, rost, deb javob beradi Rumiy. Shunda haligi yosh tolib, sunniylik oqimining ashaddiy tarafdori ustoz Rumiyni haqorat qiladi. Uning bu ishidan majlis ahli, ayniqsa, Rumiyni qattiq harmat qiladigan shogirdlari larzaga keladi. Lekin ustoz yuzidagi hotirjamlikni sira o'zgartirmasdan" Siz aytgan so'zlardan bilan ham birdirman" - deb javob qaytaradi. Shunda savol bergan haligi tolib o'z qilmishidan qattiq hijolat bo'lib, uyalganidan majlisni tark etib ketishga majbur bo'ladi. Ho'sh, ustoz Rumiyni aynan shunday ohang, og'ir bosiqlik bilan javob qaytarishga undagan narsa nima? Bu ulug' murabbiy va ustoz mahoratining mahiyatini belgilaydigan shahsiy hususiyatlaridir. Demak, yuqorida aytilgan fikrlardan shunday hulosaga kelish mumkin: pedagogik mahorat faoliyat jarayonida namoyon bo'ladi, lekin unga olib borilmaydi, u mahsus umumiy ko'nikmalarning yuqori darajada rivojlanganligi bilan harakterlanadi. Ammo asosiysi bu ham emas. Asosan, o'qituvchining shahsi, uning tutgan yo'li, o'z faoliyatini yuqori professional darajada boshqara olish qobiliyati muhim ahamiyat kasb etadi. Binobarin, pedagogik mahorat mohiyatini anglash uchun, avvalo, pedagogik faoliyatning o'qituvchi shahsiga nisbatan talabalarini ko'rib chiqamiz. 
Bu jarayonda ilg'or o'qituvchining pedagogik mahorati va tajribalarini boshqa o'qituvchi o'rganishi, undan ijodiy foydalanishi va o'z faoliyatini ilg'or tajribalar bilan boyitishi zarur. O'qituvchining pedagogik mahorati asosan sinf, auditoriya mashg'ulotlarida yaqqol ko'rinadi. Chunki o'quv mashg'ulotlari o'zining mazmun va mohiyatiga ko'ra o'qituvchining o'quv yurtidagi asosiy ishidir. Shu sababli u ilmiy, g'oyaviy va ommabop bo'lishi, turmush bilan o'quvchi talabalarning tayyorgarlik darajasi bilan bog'lanishi zarur.

Ta'lim jarayonida o'qituvchi bilan o'quvchi talabalar o'rtasida o'zaro jonli til, fikr olishuv, samimiy munosabat, hurmat, asosiy maqsadga erishishda hamkorlik lozim. Mazmuni sayoz, amaliy tajribadan, turmushdan ajralib qolgan, umumiy so'z va quruq nasihatgo'ylikdan iborat bo'lgan, rasmiyat uchun yuzaki o'tkaziladigan dars ma'ruza va boshqa o'quv mashg'ulotlari o'quvchi talabalarni qiziqtirmaydi, ularni ilmiy, g'oyaviy jihatdan yetarli oziqlantirmaydi. Shunday ekan, o'quv mashg'ulotlarini shunday tashkil etish kerakki, uning ta'sirida talabalarda shu fanga nisbatan turli qarashlar, ilmiy tafakkur va e'tiqodlar vujudga kelishi va shakllanishi darkor.

Ta'lim va tarbiya jarayoni ta'sirchanligining yanada yuksak bo'lishi, avvalo o'qituvchining ilmiy salohiyatiga, yoshlar oldidagi obro'siga, shaxsiy sifatlariga, ilmiy iste'dodiga, ta'lim sohasidagi tajriba va mahorati hamda o'quvchi talabalar bilan o'rnatilgan do'stona munosabatiga bog'liqdir.

Pedagogik faoliyat samarasi o'qituvchining pedagogik qobiliyati qay darajada shakllanganligiga ham bog'liqdir. Qobiliyat faoliyat jarayonida paydo bo'ladi va rivojlanadi deb ta'kidlaydi professor M.Ochilov hamda o'qituvchi qobiliyatining quyidagi turlarini tavsiya etadi. Jumladan, bilish qobiliyati, tushuntira olish qobiliyati, kuzatuvchanlik qobiliyati, nutq qobiliyati, obro' orttira olish qobiliyati, muomala qila bilish qobiliyati kabilar.

Pedagogik qobiliyat va mahorat o'qituvchida osonlik bilan shakllanmaydi. Bu kasbni tanlagan kishi o'z maqsadiga erishish uchun uzluksiz o' qishi, o'rganishi va izlanishi, ijodiy mehnat qilishi, mustaqil yurtimizda bo'layotgan voqelikni tez anglashi va o'z mehnatining mamlakat uchun qanchali zarurligini chuqur his qilishi zarur.

O'qituvchining pedagogik mahorati haqida fikr yuritar ekanmiz, uning ongliligiga, milliy g'oya va mafkuraga sodiqligiga, bilim va fikr doirasining kengligiga, o'z vazifasiga munosabatiga e'tibor bermoq kerak. Ayniqsa, pedagogik mahoratda o'qituvchining fikr doirasi keng bo'lishi zarurligini alohida hisobga olish lozim. Chunki, kishida bilim, fikr mukammal bo'lmasa, u kamolotga erisha olmaydi. Darhaqiqat, kishi u yoki bu masalani, albatta fikr orqali hal etadi. Shuning uchun pedagogik mahorat sohibi bo'lishga intilgan kishi, shubhasiz, o'z bilimini doimo kengaytirishi, o'quvchi, talabaga ma'naviy-axloqiy ta'sir etuvchi g'oya va fikrlarni yangilab borishi zarur. Buning uchun ko'p o'qishi, o'rganishi lozim. O'qituvchining pedagogik mahoratiga baho berishda uni ta'limni qay darajada tashkil qila bilishi muhim ahamiyatga egadir.

Uzluksiz ta'limda dars va ma'ruzalarni mukammal tashkil qilishi o'qituvchining birinchi navbatdagi vazifasidir. Yuqori saviyada o'tilgan mavzular yoshlar ongida uzoq saqlanadi, ularning imon, e'tiqodi va mafkuralarining shakllanishiga samarali ta'sir ko'rsatadi. Shu sababli, o'qituvchining ilmiy saviyasi o'z burchiga munosabati, yoshlarga murabbiylik ishtiyoqi, pedagogik mahorati, dastlab dars va ma'ruzalarda ko'rinadi. Fan o'qituvchisining faoliyatiga beriladigan baho darajasini ham dars va ma'ruzaninng sifati belgilaydi.

Shundagina, mamlakatimizning kelajagi bo'lgan o'quvchi yoshlarimiz o'z murabbiylarini nomini zo'r ehtirom, chuqur minnatdorchilik bilan tilga oladilar. Buning uchun har bir o'qituvchi O'zbekiston Respublikasining ta'lim to'g'risidagi Qonunida ko'rsatilganidek, o'z fanlari bo'yicha tegishli ma'lumot egasi, yuksak kasbiy tayyorgarligi va yuqori axloqiy fazilat egasi bo'lishlari darkor.

Xo'sh pedagogik mahorat nima va u nimalardan tashkil topgan? Bu fahm-farosat va bilimlarning chinakam ilmiyligi, tarbiyadagi qiyinchiliklarining yengishga qodir bo'Igan nufuzli rahbarlik bolalar qalbining qandayligini his qilish mahorati, ichki dunyosi nozik va zaif bo'lgan bola shaxsiga mohirlik bilan avaylab yondashish, donolik va ijodiy dadillik, ilmiy tahlil, xayol va fantaziyaga bo'Igan qobiliyat mujassamdir.

Pedagogik mahoratga pedagogik bilimlar, fahm-farosat bilan bir qatorda pedagogik texnika sohasidagi malakalar ham kiradi, ular tarbiyaga ozroq kuch sarflab ko'prok natijalarga erishish imkonini beradi. Har bir mohir pedagogning shunday zarur 
bo'lgan umumiy pedagogik malakalarni shakllantirish bilan bog'liq bo'lib, mazkur masalalarni hal qilish pedagogdan odatdan tashqari kuch-g'ayratni, qatiyatni, tirishqoklikni, tadqiqotlarni olib borishga intilishni, yangi vaziyatga, yangi kollektivga kirish qobiliyatini, samimiyatni, to'g'rilik va halollikni, o'tkir aql-idrokni bir vositani boshqasi bilan tekshirib kurish malakasini talab qiladi. A.S.Makarenko aytganidek, "Agar pedagog mahoratni egallamas ekan, agar u bolalar muhitidagi ilg'or kuchlarga tayana olmas ekan, ularning o'stirishini rag'batlantirib, eng yaxshi faoliyatlarini rivojlantira olmas ekan, u muqarrar ravishda shaxsiy ta'sir ko'rsatishni mutloqlashtirib boradi, ya'ni o'ziga eng oson yo'Ini tanlaydi. CHinakam mahorat bilan obrutalablik bir biri bilan sig'isha olmaydi. Agar chinakam mahoratli pedagog hamma vaqt munosabatlar sistemasi bolalarning ijodiy kamolatiga yordam berishi lozimligini o'ylasa obro'talab pedagog ularning mustaqil faoliyatini nihoyatda toraytirib, ularning so'zsiz quloq solishlarini yoqtiradi, bu bilan bolalar muhitidagi tarqoqlikka ko'maklashadi." Pedagogik mahorat o'ziga bolalar haqidagi ta'lim tarbiya jarayonini tashkil etish va uning mazmuni, metodlari haqidagi keng bilimlarni qamrab oladi. Bu bilimlar umumiy pedagogik madaniyatni tashkil etadi, o'qituvchi tarbiyachi bu madaniyatni egallamas ekan hech vaqt o'z kasbining chinakam ustasi bo'la olmaydi. Zamonaviy o'qituvchiga birgina umumiy madaniyatning o'zi kifoya qilmaydi. Bolalarni kuzatish, ularni o'sishidagi muhim narsalarni jamiyatda vujudga kelgan asosiy g'oyalar bilan taqqoslash, ularni rivojlanish yo'llari va usullarini aniqlash turli vositalar, tarbiyaviy ta'sir ko'rsatish usullarining o'zaro bir-biriga o'tishi dialektikasini chuqur tahlil qilish, pedagogik izlanishlar va yutuqlarni ilmiy jihatdan bir sistemaga solish malakalari zarur bo'ladi. Pedagogik mahoratning asosiy tarkibiy qismlari quyidagilardan iboratdir:

a) o'qituvchi faoliyatining insonparvarlik yo'nalishi;

b) ixtisosga doir bilimlar mutaxasislik fanini, uni o'qitish metodikasini pedagogika va psixologiyani chuqur bilish;

v) pedagogik qobiliyat (bilish, tushuntira olish, ko'zatuvchanlik, obro' orttira olish, to'g'ri muomala qila olish, kelajakni ko'ra bilish, diqqatni taqsimlay olish qobiliyatlari va pedagogik nazokat odob-axloq);

g) pedagogik texnika (nutq malakasi, mimik pontamimik ifodaliligi, o‘z hissiy holatini boshqarishi.)

Pedagogik mahorat-bu pedagogik (o'quv tarbiyaviy) jarayonining barcha shakllarini eng qulay va samarali holatda tashkil etish, ularni shaxs kamoloti maqsadlari tomon yo'llantirish, tarbiyalanuvchilarda dunyoqarash, qobiliyatni shakllantirish va ularda jamiyat uchun zarur bo'lgan faoliyatga moyillik uyg'otishdir.

Pedagogik mahoratning biz yuqorida ko'rib chiqqan tarkibiy qismlari, uni sistemaviy harakterga ega ekanligini anglatadi. Pedagogik mahoratning yaqqol tashqi belgilari: faoliyatni aniq maqsadga yo'naltirilganligi, vazminlik, mulohaza yuritish, o'quvchilar bilimini puxtaligi, eng maqbo'l vositalarni tanlanganligi, o'z faoliyatiga ijodiy yondoshuvi.

Muhandis-pedagog o'z maxoratiga quyidagi bosqichlarda erishishi mumkin: Psixologiya va pedagogika turkumidagi fanlarni chuqur o'rganish; bo'lish;

-Maxsus va umumtexnik fanlar, ularni o'qitish metodikasidan puxta bilimga ega

-Pedagogik amaliyotda faol ishtirok etish va uni samarali o'tkazish;

-O’z faoliyatini doimo taxlil qilib, unga nisbatan tanqidiy munosabatda bo'lish, boshqalar tajribasini o'rganish;

-O’z ustida mustaqil ishlash, malaka oshirish kurslarida o'qib borish.

Adol`f Disterveg (1790 - 1866) Yomon o`qituvchi haqiqatni aytib berib qo`ya qoladi, yaxshi o`qituvchi esa haqiqatni topishga o`rgatadi.

Shunday ekan o'qituvchi va murabbiylarimiz darslariga mahorat bilan yonashib, yoshlarimiz o'z murabbiylari darsidan har jihatdan mamnun bo'lsinlar. Ularda romantik orzular uyg'onsin, tafakkuri rivojlansin, amaliy faoliyat, ijodiy qobiliyat, o'qisho'rganish va mehnatga havas kuchaysin. Ular o'quv mashg'ulotidan so'ng olgan baholari bilan emas, balki bilim va malaka hosil qilganliklarini, ma'naviy oziq olganliklarini his qilsinlar. Ta'limning mazmundor, qiziqarli va tushunarli bo'lishi ustoz bilan shogirdlar qalbini, ruhini bir-biriga mustahkam bog'laydi, ular o'rtasidagi samimiy hurmat va o'zaro ishonchni mustahkamlaydi. Buning uchun o'qituvchi avvalo, o'z fanini va uni o'qitish yo'l-usullarini mukammal o'zlashtirib olishi, o'qituvchi-murabbiyga xos 
madaniyatning yuqoriligi, o'z shogirdlariga hurmat va muhabbat, ular hayotiga qiziqish va ruhiy holatlarni bilish va tushunish, bosiqlik, his-tuyg'ularini boshqara olishlari, tashqi ko'rinishi, kiyinish madaniyatiga e'tibor berishlari, nutq madaniyatining yuqoriligi, jamoat ishlarida faolliklari, ayniqsa, omma o'rtasida ilmiy-ma'rifiy va ma'naviymadaniy ishlar targ'ibotchilari bo'lishlari lozim.

Foydalanilgan adabiyotlar:

1. Karimov I.A. Bizning bosh maqsadimiz - jamiyatni demokratlashtirish va yangilash, mamlakatni modernizatsiya va isloh etishdir. T.: “O'zbekiston”, 2005.

2. O'zbek tilining izohli lug ati. Davlat ilmiy nashr. 2006.

3. Ochilova G. Pedagogika. T.: 2005

4. G'oziyev E.G. Umumiy psixologiya. Toshkent. 2002.1-2 kitob.

5. Zamonaviy ta'lim texnologiyalari: mazmuni, loyihalashtirish va amalga oshirish. Ekspres qo'llanma. T. 2001.

6. Xalq ta'limi. Jurnal. 2005 y. 1-2 sonlar

7. G.N.Najmiddinova Pedagogik mahorat kursining tehnologiyalashtirilgan ma'ruza matni T. 2008 
удК 378

\section{ОСОБЕННОСТИ УЧЕБНОЙ ДЕЯТЕЛЬНОСТИ И ФОРМИРОВАНИЕ ЛИЧНОСТИ В МЛАДШЕМ ШКОЛЬНОМ ВОЗРАСТЕ}

С.Ю. Акбаров ${ }^{1}$

Аннотация

В данной статье имеет место материалы по учебной деятельности и формирование личности учеников младшего школьного возраста. Анализ психических новообразований и изменений социальной ситуации развития в младшем школьном возрасте.

Ключевые слова: учебная деятельность, младший школьный возраст, психическое развитие, формирование личности, социальные ситуации развития.

Kichik maktab yoshi davri(6-7 yoshdan 9-10 yoshgacha)ga qadam qo'ygan bola, ta 'lim olish uchun tabiiy va ruhiy jihatdan tayyor bo'lib, uning psixikasi bilim olishga yetarli darajada rivojlangan bo'ladi. Ushbu yoshdagi bolada idrokning o'tkirligi, ravshanligi, aniqligi, xayolot olamining yorqinligi, xotiraning kuchliligi, tafakkurining yaqqolligi ko'zga tashlanadi, ular o'z qiziquvchanligi va ishonuvchanligi bilan boshqa yoshdagi bolalardan farqlanib turadilar.

Kichik maktab yoshidagi bolalarning asosiy faoliyati o'qish xisoblanadi.

Bolaning maktabga borishi, uning psixik taraqqiyoti va shaxs sifatida shakllanishi uchun katta zamin tayyorlaydi va keng imkoniyatlar yaratib beradi.

Kichik maktab yoshidagi bola o'z kundalik turmush tarzining tubdan o'zgarganliini, unga yangi majburiyatlar: har kuni maktabga borish, o'quv faoliyati talablariga bo'ysunish, o'qituvchi bajarish to'g'risida o'ylay boshlaydi. Oiladagi kattalar bolaning erishgan yutuqlarini maqtov bilan siylaydilar, uni nazorat qiladilar, unga nisbatan yangicha muomala va munosabatlarning paydo bo'lishi oiladagi ijtimoiy maqomning o'zgarganligini chuqur his etishiga, shu bilan birga o'z-o'ziga nisbatan munosabatining o'zgarishiga ham ijobiy ta`sir ko'rsatadi.

Kattalar bolalarga vaqtni to'g'ri taqsimlashga, a'lo baholarga o'qish, bo'sh vaqtida o'ynash, sayr qilish va uy vazifalarini o'z vaqtida bajarishga o'rgatadilar, bola sekin-asta o'quvchi rolini, ya`ni alohida ijtimoiy o'rinni egallaydi.

Kichik maktab yoshidagi o'quvchi saxslararo munosabatlar tizimida xam o'ziga xos maqomga erishadi, uning ota-onasi, yaqinlari, atrofdagi kishilar unga endi yosh boladek emas, balki o'ziga yarasha vazifalar va majburiyatlarni bajaradigan aloxida shaxs sifatida munosabatda bo'ladilar.

Bola o'z oilasi, sinfdoshlari davrasida o'z o'rnini anglab yeta boshlaydi, ushbu yoshda "Men shuni hohlayman" motiviga qaraganda "Men bu ishni bajarishim kerak" motivi ustunlik qila boshlaydi. Ilk maktab yoshidagi o`quvchilarning maktab ostonasiga kirishlaridagi hadik, hayajon, ikkilanish kabi hissiy kechinmalar muayyan qiyinchiliklarni keltirib chiqaradi.

Bolaning jismoniy taraqqiyoti. Kichik maktab yoshidagi o'quvchining jismoniy o'sishi, ruhiy taraqqiyot bilan nisbatan uyg'unlikda kechadi, uning bo'yi va og'irligi, o'pkasining havo sig'imi mutanosib tarzda o'sadi, lekin bolaning ko'krak qafasi, qo'l va oyoq suyaklari, umurtqa pog'onasida hali tog'aysimon to'qimalar uchraydi, bu esa tayanch-harakat tizimida to'la suyaklanish amalga oshmaganligidan darak beradi. Bosh miya po'stlaq qismining analitik-sintetik faoliyati yanada takomillashadi, nerv jarayonlarining qo'zg'alishi va tormozlanishi o'rtasidagi munosabat o'zgaradi, ihtiyoriylik kuzatiladi, biroq qo'zg'alish nisbatan ustunlikka ega bo'ladi, shuning uchun ham, kichik maktab y bolaning to'laqonli jismoniy o'sishiga g'amho'rlik qilish, undagi jismoniy toliqishning oldini olish, o'quv faoliyati va dam olish tartibiga qat iy amal qilish maqsadga muvofiq.

${ }^{1}$ Акбаров Саходилла Юлдашбоевич - старший преподаватель кафедры педагогики и психологии, Наманганский государственный университет, Узбекистан. 
Maktabga kiradigan davr kelgunga qadar bolalar tizimli ravishda ta`lim olish uchun imkoniyatlari yetarli darajada katta bo`ladi, ushbu davrga kelib bolaning shaxs sifatida ulg'ayishi kuzatiladi va quyidagicha namoyon bo'la boshlaydi:

- ma`lum bir qat iylikka ega bo`ladilar;

- o`z oldilariga uzoq muddatli maqsadlar qo`ya boshlaydilar;

- ba`zi maqsadlariga erishishning uddasidan chiqa oladilar.

- o`z hatti-harakatlariga ijtimoiy nuqtai nazardan baho berishga ilk bora urinib ko`ra boshlaysilar;

- burch va javobgarlik hissi namunalari yuzaga keladi.

Yetti yoshli bolalarda o'zining hissiy kechinmalarini idora etish tajribasi shakllanadi, bu esa maktab ta`limi uchun juda muhim omil hisoblanadi. Yuqoridagi fikrlar, bolaning maktab ta`limiga psixologik jihatdan tayyorgarlik darajasining oby`ektiv tomonlariga taaluqlidir, biroq psixologik tayyorgarlikning boshqa tomoni, ya'ni suby`ektiv tomonini ham e tiborga olish lozim bo'ladi.

Odatda, maktabga qadam qo'yayotgan 6-7 yoshli bola uchun maktabda o'qishga bo'lgan hohish va intilishi, katta odamlar bilan yangi shaklda o'zaro munosabatda bo'lishga tayyorlanish hosdir. O'qish kerakligi haqida bolada hech qanday shubha yo'q. Bola katta yoshli kishilarga, ya`ni o'qituvchilarga, maxsus ta'limiy-tarbiyaviy vazifalar topshirib qo'yilganini tushunadi va bajonidil qabul qiladi xamda ularning barcha ko'rsatmalarini yaxshilab bajarishga tayyor bo'ladi.

Ma'lumki, bu borada ham individual farqlar uchraydi, ayrim bolalar maktabga qushdek uchib borishga tayyor bo'ladilar, o'qish boshlangunga qadar bo'lgan kunlarni sanab yuradilar, 1sentabrdan ancha oldin, o'quv qurollari va maktab formasini tayyorlab qo'yish haqida ota-onalariga murojaat qiladilar.

Boshqa bir bolalar maktabga jon-dildan qiziqadilar, lekin vazminlik va ehtiyotkorlik bilan munosabat bildiradilar. Ba'zan "Yo'q, oyi, menga gapirib ovora bo'lmang! Men maktabga bormayman!" degan gaplarni aytadilar. Bolalar bunday gaplarni kattalarning bolalarni o'ylamay $(<<$ sen hali shoshmay tur, maktabga borasan$\mathrm{ku}$, ana shunda sening ta'ziringni berishadi $>>$, $<<$ sen u yerda ko'radiganingni ko'rasan!>> deb) qo'rqitishlari va ogohlantirishlari natijasida ham aytishlari mumkin. $\mathrm{Bu}$ jihatdan kattaroq bolalarning o'zlaridan kichikroq bolarga o'z "tajribalarini o'tkazishlari" ham alohida ahamiyatga ega bo'ladi(ma'lumki, birinchi va ikkinchi sinf o'quvchilari ba'zan ukalari va singillariga maktabdagi "mushkul axvollari" haqida gapirib berishni juda yaxshi ko'radilar). Shu bilan birga ba`zan, kattalarning nojo'ya va qo'pol hatti-harakatlari tufayli paydo bo'ladigan yaqqol salbiy kechinmalar ham bola ruhiyatiga ta`sir ko'rsatadi.

Kichik maktab yoshidagi bola rivojlanishining ijtimoiy vaziyatlari

\begin{tabular}{ll}
$\begin{array}{l}\text { Rivojlanishning ijtimoiy } \\
\text { vaziyati - bu bolaning } \\
\text { tevarak-atrofdagi olam } \\
\text { bilan munosabatlar }\end{array}$ & $\begin{array}{l}\text { «Rivojlanishning } \\
\text { ijtimoiy vaziyatlari» } \\
\text { tizimi. }\end{array}$ \\
tjtimoiy vaziyatlar & $\begin{array}{l}\text { L.S.Vigotskiy } \\
\text { tomonidan kiritilgan }\end{array}$ \\
tuzilmasida qiyidagi & bo'lib, bola \\
tarkibiy qismlar & shaxsining muayyan \\
farqlanadi: & bir yosh bosqichida, \\
Oby`ektiv sart-sharoit; & uning tevarak-atrof \\
Ijtimoiy rol; & bilan o'zaro \\
Faoliyatning yetakchi & munosabatlari tizimi \\
tipi. & asosida rivojlanishini \\
& tavsiflab beradi. \\
\hline
\end{tabular}

Kichik maktab yoshidagi bolalarning maktab sharoitiga ijtimoiy-psixologik jihatdan moslashish jarayoni, bolaning ta 'lim olishida o'ziga xos o'rin tutadi 
Bolaning maktabga moslashishiga ta`sir etuvchi omillar:

* Darslarni o'zlashtira olmaslik;

* Pedagogning salbiy munosabati;

* Sinf hamoasiga qo'shila olmaslik;

O'quv faoliyati - bilim, ko'nikma va malakalarni o'zlashtirishga qaratilgan faoliyat turi hisoblanadi. V.V.Davidov va D.B.Elkonin o'quv faoliyatida quyidagi tarkibiy qismlarni ajratib ko'rsatishgan:

$>0$ 'quv motivatsiyasi - o'quvchini faoliyatga undovchi kuch.

$>$ O'quv vazifasi - o'quvchi o'zlashtirishi lozim bo'lgan bilim.

$>$ O'quv harakatlari - o'quvchi bajaradigan sa'y-harakatlar. aniqlash.

$>$ Nazorat - bajarilgan amal va namuna orasidagi moslikni

$>$ Baho - o'quvchi erishgan muayyan bir natija samarasi.

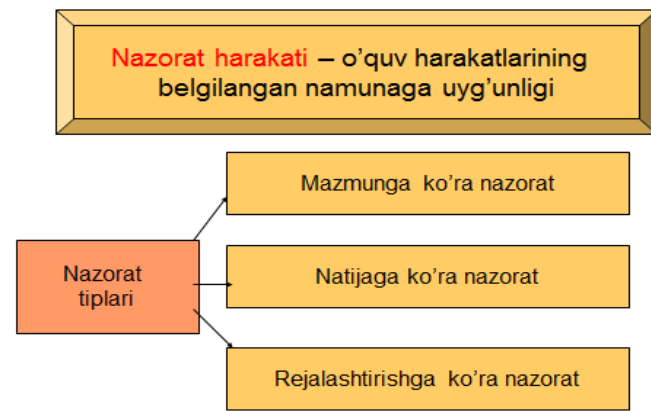

Boshlang'ich sinf o'quvchilari o'ta ishonuvchan, tashqi ta`sirotlarga juda tez beriluvchan yoshda bo'ladilar, ularning ichki olamiga kirib borish, ularning beg'ubor ruhiyatida ijobiy, insoniy fazilatlarni shakllantirish vazifasi eng avvalo o'qituvchilar va murabbiylar zimmasiga tushadi.

Mazkur yosh davrida o'qituvchining har bir gapi, har bir xatti-harakati, ta sir ko'rsatish uslubi, bola uchun xaqiqat mezoni vazifasini bajaradi, chunki o'quvchilar o'z o'qituvchilariga qattiq ishonadilar, so'zlariga quloq soladilar, bilimdonligidan hayratga tushadilar, qo'ygan talablariga so'zsiz amal qiladilar va bergan topshiriqlarni bekamuko'st bajarishga intiladilar.

O'qituvchining mazmunli va qiziqarli suhbatlar tashkil etishi, g'aroyibotlar olamiga olib kirishi, faollik sari etaklashi alohida ahamiyat kasb etadi.

Kichik maktab yoshidagi davr, shaxs taraqqiyotida nisbatan osoyishta davr hisoblansada, bolaning maktabga qadam qo'yishi, uning ijtimoiy hayotida burilish nuqtasi hisoblanadi. Aynan ushbu davrdan kattalar(ota-onalar, o'qituvchilar) va tengdoshlari(sinfdoshlari) bilan yangicha munosabatlar o'rnatiladi, bola o'zi uchun notanish muxit(maktab, sinf)ga qo'shiladi. Uning oldiga bir qator jiddiy talablarni qo'yadigan o'quv faoliyati - o'quvchining o'z hayotini qat'iy tartibda tashkil qilishga, vazifalarni bajarishga, ijtimoiy meyorlarga amal qilishga majbur qiladi.

Ta' limdagi qiyinchiliklarning asosiy sabablari

- yalqovlik;

- parishonxotirlik

- yengiltabiatlik;

- surunkali

muvaffaqiyatsizliklar;

- faoliyatdan

uzoqlashish;

- o'yinqaroqlik;

- salbiy kechinmalar.

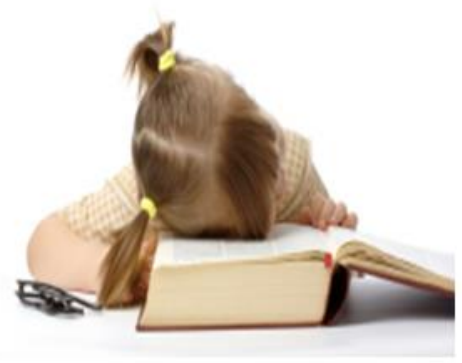


Foydalanilgan adabiyotlar:

1. Курс общей, возрастной и педагогической психологии. Выпуск 3. Под ред. М.В. Гамезо. М.: Просвещение, 1982.

2. Д.Б. Эльконин. Избранные психологические труды. М. Педагогика.1989.

3. Е.В. Андриенко. Социальная психология. Под ред. В.А. Сластенина. М.Академия.2000.

4. Л.А. Венгер, В.С. Мухина.Психология. М.: Просвещение, 1988.

() С.Ю. Акбаров, 2019. 
UDC 378

\section{PEDAGOGICAL MECHANISMS OF FORMATION OF CREATIVE} AND SOCIAL ACTIVITY IN STUDENTS

Ja.R. Mukhitdinova¹, M.M. Xayitmirzayeva²

\section{Abstract}

In this article the analysis of mechanisms of formation of skills of creative and social activity of pupils which are connected with ability of the person to realize the skills in any area is carried out.

Key words: personality, activity, skill, creativity, student.

Modern society needs socially developed people who are able to make their own decisions in a dynamically developing society. The social order for such people is reflected in the provisions of the "Federal program for the development of education", which are focused on changing the education system and the development of social activity of the individual. The development of universal skills involves the ability to organize the process of education, to integrate into it, to find their niche and use their own resources.

According to S. L. Komarova, social activity is a systemic education, which is characterized by the manifestation of the intensity of development of the totality of potential opportunities provided by society for decent life and human participation in the development of society. In order to feel the ability to actively influence the situation, a person must constantly interact with the world, forming his life position, his life meanings (D. A. Leontiev), because it is in the interaction that he begins to feel himself as part of the real world, to assess his strength (A.A.Baranov), and to enhance their social potential.

Manifestation of social activity of schoolchildren is caused by the system of the following motives:

* motives of self-determination and self-affirmation in various social communities (school, class, yard, street);

* social motives, consisting in the desire to acquire knowledge to be useful to the Motherland, society, the desire to fulfill their duty, the understanding of the need to learn and a sense of responsibility; social motives provide a solid Foundation of collectivism, responsibility for the common cause, citizenship, independence; expressed through the need for communication and interaction;

* motives of personal prestige, aimed at the desire to occupy a certain position in society; based on this desire, the motive of self-improvement;

* motives of personal achievements, aimed at the realization of the needs for selfexpression

* cognitive motives, aimed at satisfying cognitive needs;

* individual motives aimed at resolving contradictions between individual experience, internal motives and external socio-pedagogical norms and rules;

* moral motives (the motive of duty, moral motives)

Motives of manifestation of social activity are caused by aspiration of the person to satisfy the requirements and interests in interaction with society. In contrast to motives, incentives act as external stimuli to activity. In relation to social activity incentives can be numerous factors of economic, political and other nature, acting in the structure of the environment of the individual.

The motivational mechanism of social activity includes the interaction of needs, value orientations and interests, the end result of which is their transformation into the goal of the individual's activity, the goal of self-manifestation. This is determined by the fact that the realization of certain needs, attitudes, interests of the individual is possible through the manifestation of activity, since if there are no needs, then there is no need for the manifestation of activity. Also, the implementation of social activity allows

\footnotetext{
${ }^{1}$ Mukhitdinova Jamila Ruslanovna - senior lecturer, NamSU, Uzbekirztan.

${ }^{2}$ Xayitmirzayeva Muhabbat Mamazokirovna - student, NamSU, Uzbekirztan.
} 
through the mechanism of meeting the needs of one order to stimulate the needs of a higher level. In this case, the driving force of the highest order, the motive cause of social activity of the individual can be considered the internal need for purposeful participation in social life.

Social activity of a person implies such personal qualities as:

- life attitude or citizenship, which is manifested in the personal attitude to everything that happens in society, the country and the world;

- independence;

- morality;

- sociability.

Their combination characterizes a person as a socially active person.

Values act as motivational mechanisms that determine how human behavior and are the epitome of freedom and creativity, and, consequently, to the manifestation of activity, which can be considered as a significant proof of the valuable bases of social activity.

Creativity involves stepping beyond social-role attitudes personality, ability to distantsirovaniya from the situation that creates the conditions for achieving one of the main goals of the human development status of the creative person, as creativity is the gateway to the field is multi-valued, multi-dimensional, paradoxical, bisociative understanding of reality and of its development; creativity involves the actualization of notsituation as the ability of the subject to go beyond the unambiguous constructions of "external expediency". Creativity in this case is a holistic education, it is not limited to such aspects of the functioning of the human psyche, as figurative, logical, behavioral, etc., and is manifested at all levels of human mental activity.

Creativity is characterized by synergistic features, because the creative person discovers the phenomenon of creative multidimensionality, superadditivity, when a person's individual talent is realized on the basis of the sum of his talents, so creative people are dual, paradoxical, ambivalent beings, who are characterized by mutually exclusive character traits and psychological qualities.

Creative people are guided by the connection of objects and phenomena of the world, they are able to find hidden properties of objects and establish between these low-probability properties of new connections, focusing on hypothesizing-the ability to put forward hypotheses, which reveals the need to actualize the fuzzy, meaningful fractal-hologram logic of perception of the world.

In talented and brilliant people, there are more numerous connections between individual brain fields, when mental abilities depend not on the size of the brain, but on the number of connections between neurons and the speed of their establishment. In General, creativity reveals a state of spontaneity of consciousness»

Significantly determine the strategy of finding a solution to the problem, the stages of formation of personality orientation.

The first stage of the formation of the creative orientation of the personality is associated with the attitudes of the personality. Under the installation of D. N. Uznadze understood the readiness of the individual to any kind of activity. Installation on creativity is provided by aspiration, desire and inclination of the person to be engaged in any kind of creative activity. This tendency is realized in the electoral interests, and is fixed in the creative abilities and skills of a person.

The second stage of formation of creative orientation of the person is connected with ability to realize the creative interest, and to make in a certain direction any actions, to aspire to new, to show creative imagination and imagination, to be able to improvise, anticipate, creatively to initiate any ideas.

The third stage of formation of creative orientation of the personality is connected with ability of the personality to realize the skills in any area of creative activity, to be able to develop them, improve, see strengths and weaknesses. The fourth stage of formation of creative orientation of the personality is connected with creative self-realization and creative activity. Creative self-realization, according to N. Yu. Postalyuk [3], is associated with the ability to embody creative ideas, which are carried out with certain skills. In this case, in our opinion, the creative orientation has already a pronounced aspect and can be transformed into the creative abilities of the individual. 
Enrich the idea of the formation of the creative orientation of the personality and certain patterns of its implementation: one of the main patterns of formation and manifestation of the creative orientation of the personality is a historical pattern: the main historical trends of the era associated with the economy, politics, culture, social sphere, determine the quality of the creative orientation of the personality, its relevance

The creative person must always keep pace with the times, and sometimes ahead of it, which determines the historical progress of society. A creative person is able to foresee the future, meet people's expectations.

\section{References:}

1. Sokolova N.A. Formation of social activity of teenagers in the polysubject environment of additional education [Text]: monograph / N.A. Sokolova, Yu. N. Gubin. - Chelyabinsk: Publishing house Chelyabinsk. state PED. UN-TA, 2014. - 179 p.

2. http://elar.uspu.ru/bitstream/uspu/6926/2/merkyshina.pdf

(C) Ja.R. Mukhitdinova, M.M. Xayitmirzayeva, 2019. 
UDC 378

\section{METHODS OF APPLICATION OF NEW PEDAGOGICAL TECHNOLOGIES IN PHYSICAL EDUCATION CLASSES}

U.L. Qo`chqorov ${ }^{1}$

\section{Abstract}

in this article we will talk about the role of new pedagogical technologies in the organization of classes in physical education, the managerial skills of the teacher in the organization of action-meaningful and creative games

Key words:educator, technology, training, education, training.

Collecting, studying the wealth of creativity created by the Uzbek people for thousands of years, passing from generation to generation, raising the younger generation spiritually rich, morally pure, physically harmonious on the basis of these rich treasures is one of the current issues.

Consistent measures are also reflected in the decree of the President of the Republic of Uzbekistan № 5368 of 5 March 2018 “On measures to radically improve the system of Public Administration in the field of physical education and sports" on the popularization of physical education and sports in our country, creation of the necessary conditions and infrastructure for the promotion of a healthy lifestyle

Especially after Uzbekistan gained its independence, the attention to our national values and traditions became even stronger. It began to manifest itself to a different extent in all aspects of life, including in Physical Culture, one of the main parts of Education. It is noted that "physical education,"which is called the" law of the Republic of Uzbekistan on Physical Education and sports, " is an integral part of the national culture of the peoples of the Republic of Uzbekistan, an important means of physical and cultural and spiritual perfection."

And this puts great responsibility on the physical culture, which brings up the younger generation healthy and harmonious. The need for the nationalization of Physical Culture, aimed at the development of their physical qualities, the collection of the Uniting national games of our people in bunda, the introduction into life-school, the revision of ways and methods of their development, which will allow the younger generation to be brought up physically energetic.

Hara must understand the need for Physical Culture and sports for the selfeducation of anyone and persistently formulate his health on the basis of a certain system of physical training, which he liked. All-round development of physical abilities of children of our people is carried out in the process of Physical Culture, which is an integral part of Education. The purpose of Physical Culture is a long-term, organized pedagogical process, in which society is healthy, cheerful, comprehensively physically developed, trained builders who are ready for labor and Vatan protection.

In the process of Physical Culture, the following main tasks are solved: a) health strengthening tempering the organism and increasing the level of physical development as well as working capacity; B) mastering the skills and skills of movement, which will be necessary for life, including practical character; c) training the spiritual and willful quality of a person; d) cultivation of physical quality (agility, strength, dexterity, endurance);

At the same time, a rapid flow of information into the social life of the Republic is entering and covering a wide range. The rapid reception of Information, their analysis, processing, theoretically summarizing, summarizing and delivery to the listener is one of the pressing problems facing the educational system. The implementation of pedagogical technology in the educational process will serve as a positive solution to the above-mentioned pressing problem.

${ }^{1}$ Qo'chqorov Ulug'bek Lochinbekovich - lecturer, Namangan Institute of Engineering and technology, Uzbekistan. 
Educational technology is the general content of the process of achieving the educational goal, that is, the gradual implementation of the previously developed educational process on the basis of a holistic system, the development of a certain system of methods, methods and Means for achieving a specific goal, their effective, productive use and high level of management of the educational process. The central problem of educational technology is the expression from ensuring the achievement of the educational goal through the development of the personality of the educator.

Meaningful-role-playing and meaningful-action games are attractive and exciting, with excellent content as well as a variety of actions. This way introduces children to the qualities of the surrounding olam, nature, some things. Here the importance of games in this group is different. Creative games include: - games that students create on the basis of Uzbek folk tales and legends; - voluntary and meaningful games aimed at aesthetic purposes; - purposeful games, games in which the beginning and end of which the readers themselves create are different, the result of which is known; - games in which poetry is woven, songs, dances, gestures, imitations and plays are performed;-games about visual creativity, the fulfillment of what is necessary for games.

A necessary condition for improving the effectiveness of training students in the process of playing football in physical education classes is the skill management of this process by the educator. The task of the teacher in the implementation of pedagogical guidance to football games is an expression from the following: acquaintance with the content of the game; evaluation of the behavior, interaction of students during the game, the results of which are expressed in the activation of the students ' attitude to the game goals and Idea, the conduct of the game and the solution of its set of educational tasks.

The pedagogical side of the guidance to the games requires the teacher to analyze the age and specific characteristics of small, medium and large school-age students: to lay down certain goals and tasks of education, as well as to divide them into parts or groups, to determine the most correct forms, techniques and means of educating small and large school-age students.

We can observe that training on the basis of new pedagogical Technologies is much more effective than training on the basis of traditional methods. In this process, an increase in the technique, tactics, general and special physical training of students playing football, as well as their theoretical knowledge will also develop. Summarizing the above descriptions, we can say with full confidence that educators and parents in the family are impregnated with a sense of nurturing vatan -these are the main factors that traditionally shape the educational process if it is conducted on the basis of new pedagogical technologies.

References:

1. Volkov L.V. Biologicheskie i pedagogicheskie osnovi sovremennix technological sportivnoy podgotovki detey I molodeji. Warsaw, Academy fizicheskoy Kul, $2001 \mathrm{~g}$. 44- S.

2. Platonov V.N.Y., Saxnovsky K.P. Podgotovka yunogo sportmena. Kiev, rejected. shk. 1988 g. 288- S.

3. Salamov R.S. Moving games in the process of physical training of students. "Science to sports", 2005 g. 3- S.

(C) U.L. Qo`chqorov, 2019. 
UDC 378

\section{THE MECHANISM OF LANGUAGE ACQUISITION OF GAMING TECHNOLOGIES IN ENGLISH LESSONS}

B. Matkarimova ${ }^{1}$

\section{Abstract}

This article discusses game technologies as mechanisms of language acquisition in English lessons. The impact and effectiveness of games in training sessions is discussed.

Key words: game, mechanism, learning, language, efficiency, technology.

Recent years show a significant increase in interest in the English language. It is recognized as the language of professional communication in different spheres of activity. The most important task of the teacher is to increase motivation to learn English.

Nowadays, teachers revise the arsenal of influence on the minds, will, emotions of students in order to introduce them to the rich world of culture and traditions of the country of the studied language. The ways and methods of formation of all types of speech activity are reviewed: reading, speaking, listening, writing. Activation of the educational process, stimulation of cognitive activity contributes to the introduction of the learning process, along with traditional classes, gaming technologies.

The reason for such increased interest in various kinds of games is, first of all, a departure from traditional forms and methods of training. It should also be noted that while maintaining a sufficiently high motivation, there is a decrease in cognitive interest in learning a foreign language. This phenomenon occurs due to the fact that students face some difficulties that seem insurmountable to them. Game activity, being one of the methods stimulating educational and cognitive activity, allows to use all levels of assimilation of knowledge. Therefore, the interest in the use of game technologies in foreign language lessons is not accidental.

The problems of stimulation and motivation to learn a foreign language using entertaining materials and game teaching techniques are presented in the research of many domestic scientists (I. L. BIM, S. T. Zanko, S. S. Polat, E. I. Passov, V. M. Filatov, etc.). In the practice of teaching foreign languages, numerous textbooks, methodological developments, materials for a variety of games with the use of foreign language material are used.

Game technologies as a condition for creating a motivational basis for teaching a foreign language. Increasing the motivation of students to educational activities is one of the topical issues of didactics. The real way to maintain cognitive motives is " the inclusion of activities to master a foreign language in activities that have a certain personal meaning for students (play, communication, work, knowledge)."

Motivation determines the importance of what is learned and assimilated by students, their attitude to educational activities and its results.

Feature foreign language as a subject is that the activity involves training of foreign language speech activity, i.e. the activity of communication, in which are formed, in addition to knowledge, their language skills. Cognitive motives of students contained in the educational activity, give this activity a personal meaning. The source of cognitive motives is the conscious cognitive need of students. The real needs of foreign language learners are related to the desire to communicate in this language, to Express their opinions, to use the language orally and in writing, to own it. The latter leads to the need for a thoughtful selection of means and methods of teaching foreign language speech activity to maintain motivation. In this regard, the use of game techniques of teaching foreign language communication is of particular importance.

\footnotetext{
${ }^{1}$ Matkarimova Barno - English teacher, Fergana polytechnic institute, Fergana, Uzbekistan.
} 
Engaging the game as a method of learning is an effective tool for managing educational activities (activities for mastering foreign language communication), which activates the mental activity of students, allowing them to make the learning process exciting and interesting.

Elkonin D. B. in his book "Psychology of the game" gives the following definition of the game: "the Game-objectively-primary spontaneous school, the apparent chaos, providing the child with the opportunity to get acquainted with the traditions of the behavior of the people around him.»

The most acceptable for us is the definition given by A. A. Derkach, which is called a game used in the educational process as a task, containing an educational (problem, problem situation), the solution of which will ensure the achievement of a certain educational goal.

From the disclosure of the concept of the game we can distinguish a number of General provisions:

1. The game acts as an independent type of educational activity of children of different ages.

2. Game for children is the most free form of their activity, which is realized, studied the world, opens a wide scope for personal creativity, activity of selfknowledge, self-expression.

3. The game is the first stage of the child's activity, the initial school of his behavior, normative and equal activity of younger students, adolescents, youth, changing their goals as students grow up.

4. The game is a practice of development. Children play because they develop and develop because they play.

5. Game-freedom of self-disclosure, self-development based on the subconscious mind and creativity.

6. The game is the main sphere of children's communication; it solves the problems of interpersonal relations, acquires the experience of people's relationships.

The game is a powerful incentive to learn a foreign language and an effective technique in the Arsenal of a foreign language teacher. The use of the game and the ability to create speech situations cause students to be ready, willing to play and communicate.

So. We can conclude that the game does not have a single precise definition. Different scientists define it in their own way. But. obviously, any game involves a certain goal, knowledge of the rules, as well as an element of fun.

An educational game is a specially organized task that requires the tension of emotional and mental forces. Positive is the fact that the student speaks a foreign language, therefore, the game method is fraught with great learning opportunities. The game for students is, first of all, an exciting experience.

Playing in the classroom contributes to the implementation of important methodological tasks:

* Creation of psychological readiness of students for speech communication;

* Ensuring the natural need for them to repeat language material many times;

* Training students in choosing the right speech option;

Everyone is equal in the game. It is feasible for almost every student, even those who do not have a sufficiently strong knowledge of the language. Moreover, a student who is weak in language training can become the first in the game: resourcefulness and ingenuity are more important than knowledge in the subject. A sense of equality, an atmosphere of enthusiasm and joy, a sense of the power of tasks - all this allows the student to overcome the shyness that prevents the free use of words in the speech of a foreign language, reduces the fear of mistakes, and has a beneficial effect on the results of training. In the game everything is "make-believe", there is an opportunity to hide behind the mask of someone else, i.e. to absolve yourself of responsibility for the mistakes and present the situation in the light of the fact that "I am not me, but the hero I portray". In this case, part of the psychological stress of communication is removed. Language material is absorbed imperceptibly, and at the same time there is a sense of satisfaction. 


\section{References}

1. Zhukova, I.V. Didactic games in English lessons / / First of September. English, 2006.

2. Mukhina, V.S. Child psychology. - Moscow: Enlightenment, 1985.

3. Solovova, E.V. Methodology of teaching foreign languages: basic course of lectures / E. V. Solovova-M.: Education, 2005.

4. Stepanova, E.L. Game as a means of developing interest in the studied language // IYASH. - 2004.

5. Stronin, M.F. Educational games at the English lesson / M.F. Stronin-M.: Enlightenment, 1984.

(c) B. Matkarimova, 2019. 
UDC 378

ON THE ROLE OF THINKING IN LANGUAGE LEARNING

D.M. Khamrakulova ${ }^{1}$

\section{Abstract}

The article analyzes such psychological factors as thinking and speech in the study of a foreign language.

Key words: thinking, language, speech, factor, learning, cognitive process.

As you know, the languages of mankind are different, thinking is one. This allows people of different nationalities to communicate (if you learn a foreign language). Difficulties, of course, arise, but surmountable, because it is really impossible to communicate only when the thinking of your "interlocutor" is fundamentally different. But read about it in science fiction. And we are people of the same planet, and although the specifics of thinking in each case is quite bizarre, we are able to understand each other. The areas of language and thought can be depicted as two partially intersecting circles.

Not everything in thinking belongs to language, and in language not everything can be counted as thinking. For example, thinking happens without speech: the monkey is able to guess how with a stick you can get a banana - this is the so-called practical thinking. You've probably heard the expression " practical mind." Man "practical" is able to make the right decisions, acts "smart", but to explain in words why he did so, and not otherwise, he is likely to be difficult. Visual and imaginative thinking often prevails among people of art: artists, Directors. A person with this type of thinking prefers to think not in words, but in pictures, images, representations. Finally, there is verbal thinking, that is, verbal thinking. Sometimes it is called verbal-logical or just logical.

Human thought is always expressed in language, which in a broad sense is called any sign system that performs the functions of formation, storage and transmission of information and acts as a means of communication between people. Outside of language, vague impulses, volitional impulses, which, though important, are incomparable with speech, revealing the intentions, feelings and experiences of a person, can only be conveyed by means of facial expressions or gestures. Thinking is always connected with units of language; without them thought cannot attain distinctness and clarity, representation cannot become a concept. However, the relationship between language and thought is quite complex.

Language is impossible without thinking. The word arises from the subjective perception of objects of the external world by man; it is the imprint not of the object itself, but of its image, created by this object in our consciousness.

Methodist E.V. Krivorotova also considers such general didactic principles as problemativeness, creativity and consistency as the most important in the formation of linguistic thinking. In the work aimed at the development of linguistic thinking of schoolchildren, it is necessary to carefully select and systematize grammatical materials in accordance with such principles as scientific, accessible, problematic, as well as the principle of grammatical saturation. It is important that the selected didactic material corresponds to a certain composition of language knowledge and skills "the totality of which constitutes the substantive and operational aspects of such thinking and provides a person with fluency in the language." In order for the process of formation of linguistic thinking was the most effective, you should follow some conditions, for example: deliberate setting of a teacher to give students a better understanding of the relationship between "form-value" language, the relationship between language and extralinguistic reality, and also about the specifics of lexical and grammatical meanings embedded and expressed in words.

In this case, the objects of the real world do not become objects of thought themselves, they can not get inside the thought - they are presented to thinking by language,

\footnotetext{
${ }^{1}$ Khamrakulova Dildora Muhammadali kizi - teacher of NamSU, Namangan, Uzbekistan.
} 
which, although it develops itself by the power of thought, but inevitably has a form and represents the world in a certain form. The perception and understanding not only of abstract phenomena, but also of concrete objects depends on the way in which language has designated them out of a multitude of possible ways.

Language reflects reality not directly, but through two stages: from the real world to thinking and from thinking to language. And although thinking was ahead of language, its results, taking shape in language, are somewhat modified (thought can not be fully reflected in the word). Therefore, language becomes a separate participant in communication and further development of thinking, it can not be a simple form for thought, it can simultaneously hide part of the thought and complement the thought of language associations.

The need of thought for a concept and the consequent desire for its elucidation must precede the word, which is the expression of the complete clarity of the concept. Thinking develops and renews itself much faster than language, but without language, thinking is only a "thing for itself." Unspoken thought is not the clear, distinct thought that helps a person to comprehend the phenomena of reality, it is, rather, foresight, and not actually knowledge.

(C) D.M. Khamrakulova, 2019. 
Психологические науки

Удк 159.9

МОТИВАЦИЯ ДЕЛИКВЕНТНОГО ПОВЕДЕНИЯ ПОДРОСТКОВ

Д.Х. Эргашева ${ }^{1}$, Д.М. Муминова²

Аннотация

В статье освещается основные причины подростковой преступности, виды подростковой преступности и мотивация к совершению преступлений.

Ключевые слова: деликвент, мотивация, поведение, эмоции, идеал, потребность, активность, бессознательность.

Yosh avlod tarbiyasi haqida gapirganda, Abdurauf Fitrat bobomizning mana bu fikrlariga har birimiz, ayniqsa,endi hayotga kirib kelayotgan o’g il-qizlarimiz amal qilishlarini men juda-juda istardim. "Xalqning aniq maqsad sari harakat qilishi,davlatmand bo'lishi, baxtli bo'lib izzat-hurmat topishi, jahongir bo 'lishi yoki zaif bo'lib xorlikka tushishi, baxtsizlik yukini tortishi, e`tibordan qolib o`zgalarga tobe va qul, asir bo`lishi ularning o`z ota-onalaridan bolalikda olgan tarbiyalariga bog liq" Haqiqatan ham hozirgi vaqtda yoshlar tarbiyasi biz uchun o`z dolzarbligi va ahamiyatini hech qachon yo`qotmaydigan masala bo`lib qolmoqda.Bugungi tez o`zgarayotgan dunyo insoniyat oldida,yoshlar oldida yangi-yangi, buyuk imkoniyatlar ochmoqda.Shu bilan birga,ularni ilgari ko`rilmagan turli yovuz havf- xatarlarga ham duchor qilmoqda.G`arazli kuchlar sodda, g`o’r bolalarni o`z ota-onasiga, o`z yurtiga qarshi qayrab ularning hayotiga,umriga zomin bo'lmoqda. [1.22]

Zamonaviy kriminologiyada o'smirlar va yoshlar jinoyatchiligiga sabab bo'luvchi ikki yuzga yaqin omillar aniqlangan,"Har qanday jinoyatning ildizini ko'proq inson tarbiyalanayotgan muhitdan izlash kerak"- deydi taniqli rus adibi

F. Dostoevskiy. Darhaqiqat, bola tarbiyasi bilan shug'ullanuvchi ota-ona bolaning o'rtoqlari tengdoshlari kim, u qayerga boryapti, nima ish bilan shug'ullanayotganligini hammasini nazorat qilib turishi kerak.

Mutaxassislar tomonidan o'smirlar jinoyatining asosiy sabablari quyidagicha ko'rsatib o'tilgan:

1. Yashash, o'qish yoki ish joyidagi muhitning salbiy ta`siri.

2. O’qishni tashlab ketgan o'smirlar yoki o'spirinlar.

3. Bo'sh vaqtni to'g'ri taqsimlay olmaslik.

4. O'smirlarning noto'g'ri tarbiyalashga olib keluvchi shart-sharoitlar.

5. Yoshi katta jinoyatchilarning salbiy ta`siri.

6. Zo'ravonlik va noqonuniy harakatlarni ifodalovchi kitoblar va kinofilmlar ta`siri.

7. Bolalar xulq-atvorni nazoratsiz qoldirish.

8. Madaniy hordiq chiqarishni tashkil etishdagi kamchiliklar.

O'smirlar jinoyatining sodir etilishiga ko'ra turlari quyidagicha farqlanadi.

- Jinoyatni oldindan puxta o'ylab sodir etilgan jinoyatlar; jinoyatlar.;

- O’ylamasdan kutilmaganda yuzaga kelgan va fikrlar ta`sirida sodir etilgan

- G'arazli niyat bilan;

- Ba`zan kutilmaganda;

- Ba`zan oldindan o’ylab qo'yilgan reja bilan sodir etilishi mumkin.[2. 284b]

\footnotetext{
1Эргашева Дилором Хамидуллаевна - преподаватель кафедры педагогики и психологии, Наманганский государственный университет, Узбекистан.

2Муминова Дилрабо Муродиллаевна - преподаватель кафедры педагогики и психологии, Наманганский государственный университет, Узбекистан.
} 
Jinoyat sodir etishga undovchi motivlar haqida so'z ketganda uni tasodifiy holatlarining yig'indisi deb qarash to'g'ri emas.

Ko'p hollarda o'smir shunday sharoitlarni o'ziga qidirib topadi. Olimlarning firicha jinoiy harakatlar ikki turdagi turtki motivlar tufayli sodir bo'lishi mumkin. Ular kishining ehtiyoj va his-tuyg'ularidadir.

Ye. I. Kulchiskayaning fikricha o'smirlar huquqbuzarligining psixologik motivlari tarkibida emotsiyalar-33,4\% dunyoqarash va tasavvurlari $-23,4 \%$, ehtiyojlar 26,4\%,qiziqishlar - 17\% ni tashkil etadi.[3.583b]

Bundan ko'rinib turibdiki jinoyatga undovchi motivlar orasida emotsiyalar "hissiyot" yetakchi o'rinlarini egallaydi. Shaxs jinoyat sodir etayotganida uning ichki psixofiziologik holatlari muhim rol o'ynaydi. Unda ichki va tashqi tormozlanish mavjud. Jinoyat sodir etilayotganda bizdagi emotsiyalar qo'zg'alish holatiga keladi. Ya`ni butun his-tuyg' ularimz ongsizlik holatiga o'tib ketadi. Jinoyatning kelib chiqishida bir nachta sabablar motivlar paydo bo'ladi. Inson qanchalik tarbiyalangan bo'lsa emotsiyalarini boshqara oladi. Lekin ayrim hollarda chegaradan chiqib ketish, ya'ni ongsizlik holatiga o'tib ketish paytlari ham bo'ladi. Xalqimizda "Jahl kelsa aql qochadi" deb bekorga aytilmagan.

Hissiyotlarning 100 dan ortiq turi mavjud bo'lib ulardan 30 tasini bevosita jinoiy harakatlarning sodir etilishida kuzatish mumkin. Sud amaliyotida ham jinoiy xulq motivlari orasida his-tuyg'ular katta o'rinni egallaydi.

Ehtiyojlar ham jinoiy xulq-atvornga undovchi motiv sifatida namoyon bo'ladi. O'smirlarda ko'proq tabiiy ehtiyojlarni qondirish ustunlik qiladi. O'smirlik davrida o'zga jinsga bo'lgan maylning paydo bo'ladi. Ba'zan jinsiy ehtiyoj ham o'smirni jinoyat sodir etishga sabab bo'lishimi. Har qanday o'smirning qarashi va tasavvurlari uning dunyoqarashini tashkil etadi. "Hayotdan lazzatlanib qol", "Ahmoqlar ishlashni yoqtiradilar" bu qabiladagi qarashlar o'smir tasavvurida ustunlik qiladi. Ideallar ham o'smir hayotida katta o'rinni egallaydi. Ideal ta`sirida o'smirlar jinoyat olamiga kirib qolishadi.

O'smirlar qiziqishlari ham beqaror va turli-tuman bo'lib, ularni moddiy va ma`naviy turga ajratishadi. Moddiy qiziqish shirinliklarga, ichishga chekishga va kiyimkechakka bo'lgan qiziqish. Ma`naviy qiziqish ham boshqa qiziqishlar kabi yuqori faollik bilan izohlanadiki, ya`ni o'smir ularni tezroq qondirishga intiladi. Bu turdagi motivlar o'smirning jinoyatchi degan nomni olishiga sabab bo'ladi.

Фойдаланилган адабиётлар руцйхати:

1. Mirziyoyev Sh.M. Qonun ustuvorligiva inson manfaatlarini ta`minlash- yurt taraqqiyoti va xalq farovonligining garovi T.”O'zbekiston"-2017. 22b

2. Nishonova Z.T. va boshqalar Psixodiagnostika va eksperimental psixologiya T. "Tafakkur bo'stoni"-2011. 284b

3. Maklakov A.G.Obshaya psixologiya: uchebnik dlya vuzov. SPb: Piter, 2008.- 583s 
УдК 159.9

\section{ЗНАЧЕНИЕ ИГР В УСТРАНЕНИИ РЕЧЕВЫХ НЕДОСТАТКОВ У ДЕТЕЙ}

Д.А. Хомидова ${ }^{1}$

Аннотация

В этой статье приведены значения игр, используемых в устранении некоторых недостатков в произношении, которые встречаются у детей, эффективные способы использования этих игр и некоторые примеры процесса проведения этих игр.

Ключевая слова: манипуляция, игровая деятельность, логопедическая проверка, речевой аппарат, метод наблюдения, эмоциональная реакция, психолого-педагогическая проверка, активность аппарата речи.

Мактабгача таълим тизими узлуксиз таълимнинг бирламчи, энг асосий бўғинидир. Шу боис болаларнинг соғлом ва билимли, етук кадрлар бўлиб вояга етишида Мактабгача таълим ташкилотлари жуда -мухим ўрин тутади. Мактабгача таълим ташкилотлари тизимини ривожлантириш, болаларни мактабгача таълим ташкилотларига жалб этиш, мактабга тайёрлаш масалалари таълим сохасидаги давлат сиёсатининг устувор вазифаларидан бири деб қаралмоқда.

Мактабгача ёшдаги болани психолого-педагогик ўрганишда мухим компонентларидан бири унинг нутқини текширишдир. Логопедик текширув логопедик амалиётда умум қабул қилинган нутқий системани ўрганишга қаратилган методикаларни ўз ичига олади. Боланинг ривожланиш даражасининг мухим кўрсаткичларидан бири бу унинг ўйин фаолиятидир, уни бахоси эса диагностик белгилардан бири бўлиши мумкин. Боланинг ўйин фаолияти орқали ривожланишидаги нуқсон ва камчиликларини эрта аниқлаш мумкин: ўйин боланинг ёш даражасига мос келмайди, ёки ўзига хос характерга эга. Бунда характерли кўрсаткич ўйинни секин аста қийинлашиб бормаслиги, ижодий ёндашувнинг етарлича эмаслиги, ўйинда ташаббускорликнинг пастлиги, шунингдек бир хилдалилиги, ўйин характерини ўзгартирувчи эмоционал реакцияларнинг йўқ ёки пастлиги. Ўйин фаолиятининг шаклланмаганлиги психик ривожланишни бир қатор ўзига хос хусусиятларни келтириб чиқаради.

Ўйин фаолиятини ўрганиш кузатув методи асосида амалга оширилади. Уни мактабгача таълим ташкилотида табиий шароитда ёки психолог хонасида ўтказиш мумкин. Ўйинни бахолашда унинг тузилиши, характери, ўйин давомида болани сўзли мулоқоти кузатилади. Текширув вақтида болага хонадаги уйинчоқларни уйнаш хамда улар билан харакатларни амалга оширишга имкон берилади. Кузатув бола уйинчоқни олдига яқинлашганидан бошланади. Ўйинчоқларга бўлган эмоционал реакцияси, уларга бўлган қизиқиши, ўйнаш хохиши хамда мақсад сари харакатларини йўналганлиги қайд этиб борилади.

Қуйидагилар бахоланади: - ўйинчоққа бўлган қизиқиши (эмоционал реакцияси хамда ифодалаши, илтимослари); - уйинчоқларни танлаши (мавзуга оид танлов, бирон-бир ўйинни ташкиллаштириш мақсадида ёки тасодифий, каттароқ ўйинчоқни олиш мақсадида, нима учун кераклигига беэътибор); - ўйинчоқлардан адекват фойдаланиш, яъни предметни унга мос бўлган холатда ишлатиш(ноадекват фойдаланиш: бола йиртади, синдиради.

Ялайди, сўради, предметни оғзига солишга харакат қилади, ўйинни мақсадсиз, мантиқсиз олиб боради); - ууйинни мустақил ташкил этиш даражаси (манипуляция, процессуал, сюжет элементли ўйин); - ўйиннинг характери (бир хиллик, ижодий); - ўйин фаолияти давомида хулқи (эмоционал реакцияси, нутқи, бошқа ўйинларга ўта олиши, катталар иштирокига муносабати). Текширув

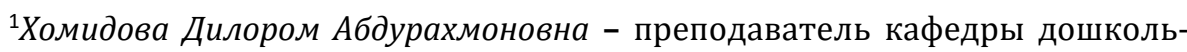
ного образования, Наманганский государственный университет, Узбекистан. 
пайтида ўйиннинг йўқлиги ривожланишда нуқсони борлигини кўрсатмайди, чунки бу шароит бола учун оддий эмас. Ўйинчоққа бўлган муносабат, ўйин даражасини характерлайди. Агар болада ўйинчоққа қизиқиш бўлмаса ёки улардан ноадекват фойдаланса, ўйинни ўзи ташкиллаштира олмаса, фақатгина катталар ёрдамида харакатларни қайтарса, унинг ақлий ривожланиши пасайган деб ўйлаш мумкин. 4 ёшдан катта болаларда сюжетли ўйинни очиб бера олмаслик ривожланишида орқада қолаётганидан далолат беради, манипуляция даражасидаги ўйин эса ривожланишдан ўта орқада қолаётганини билдиради. Бошқа кўрсатмалар билан бирга ушбу ўзига хос хусусиятлар интеллектни пасайганини кўрсатади. Мактабгача ёшдаги болаларни психолого-педагогик текшириш тавсифнома ёзиш билан тугалланади, ривожланишдаги ўрганилган фаолиятлар, шунингдек ўзига хос характеристикаси ифодаланади.

Мактабгача таълим ташкилотининг педагогик жараёнида ўйиннинг тутган ўрни жуда катта бўлиб, ўйиндан мактабгача таълим ёшдаги болаларни тарбиялаш ва уларга таълим беришда кенг фойдаланилади. Зеро: ўйин болаларнинг мустақил фаолияти бўлиб, унда боланинг рухияти намоён бўлади; ўйин мактабгача тарбия ёшдаги болалар хаётини ташкил этиш шаклидир; ўйин болаларни хар томонлама тарбиялаш воситаларидан биридир; ўйин болаларга таълим ва тарбия бершининг метод ва усулидир; ўйин болаларни ўқув фаолиятига тайёрлаш воситасидир.

“Адашма" уйини

Ўйиннинг мақсади: С-3 товушларини бир-биридан фарқлашга ўргатиш.

ўйиннинг бориши: Болаларга иккитадан расм берилади. Биттасида насос тасвирланган, иккинчисида чивин расмлари. Насос тасвирланган расмни болалар чап қўлларига оладилар. Чивин тасвирланган расмни эса ўнг қўлларига оладилар. Тарбиячи номида C ёки 3 товуши хамда бир сўзда C ва 3 товуши бор бўлган расмларни болаларга кўрсатади ва номини айтади. Масалан: сабзи, сумка, юлдуз, газета, сомса ва хаказолар. Болалар сўзда хар икки товуш бор бўлган расмларни кўрсатадилар ва С-3 товушларида қайси бири сўзнинг бошида келаётганлигини айтадилар. С ва 3 товушини расмлар орқали таққослаш керак. Машғулот пайтида номида С ва 3 товуши бўлган расмлардан хам фойдаланиш мумкин. Агар логопед болаларга бундай расмларни кўрсатса, болалар қўлларидаги расмларни кўрсатмасликлари керак.

\section{"Мушук ва сичқон" ўйини}

Ўйиннинг мақсади: Боғланган нутқда “ш” товушини мустахкамлаш.

Ўйиннинг бориши: Стулчада бир бола кўзини юмиб ўтиради. У мушук ролини бажаради. Қолган болалар сичқонлар ролини бажарадилар. Сичқонлар секин юриб мушукни олдига келадилар ва бармоқлар ёрдамида сеними, шошмай тур! ифодасини қўллаб қуйдаги шеърни айтишади. Сичқонбойлар жим бўлинг, Жим бўлинг Бароқвой қилиғидан Огох бўлинг, огох бўлинг! Шу сўзлар айтилгандан сўнг мушук уйғониб кетади ва миёв деб сичқонни қувлайди. Сичқонларнинг уйи чизиқча тортиб белгилаб қуйилади ва у ерга мушук кира олмайди. Ўйин хамма сичқонлар ушланмагунча давом этиши мумкин. Охирида қолган бола янги ўйинда бошловчи бўлади. Хамма ушланган сичқонлар “ш” товуши иштирокида 2-3 та сўз айтишлари керак.

“ўргимчак туридаги пашшалар" ўйини

Ўйиннинг мақсади: “Ж” товушини тўғри талаффуз эттиришга эришиш.

Ўйиннинг бориши: Болаларнинг бир қисми ўргимчак турини тасвирлаб, қўлларини туширган холда доира бўлиб туриб оладилар. Болаларнинг қолган қисми пашшалар бўлиб, "ж-ж-ж" деган холда, доира ичида ва атрофида учиб юрадилар. Ўргимчак тўрига илинган бола кучлироқ охангда “Ж” товушини талаффуз этади. Тўрга тушмаган бола ғолиб бўлади.

\section{“Сехрли қопча" ўйини}

Ўйиннинг мақсади: “C” товушини “Ш” товушидан фарқлашга ўргатиш.

ўйиннинг бориши: Қопчага сабзи, мушук, шар, соат, соябон, эшик, насос, идиш расмлари солинади. Болалар 2 гурухга бўлинадилар. Логопед бир томонга сичқон расмини, иккинчи томонга мушук расмини илиб кўяди. Гурухлардаги болалар биттадан навбатма-навбат чиқиб, қолган расмни олиб, унга қайси товуш 
иштирок этганига қараб ўз жойларига турадилар, яъни “C” товуши иштирок этган расмни олса, сичқон томонга "ш” товуши иштирок этган расмни олса, мушук томонга ўтадилар. Хамма олиб бўлгач, хар бир бола ўз расмини кўрсатиб номини айтади. Қолган болалар эса ўртоғи жойини тўғри танлай олганлиги ёки йуқлигини текшириб борадилар. Логопед эса болалар “с" ва “ш” товушларини талаффуз этганларида артикуляцион аппарат холати қандай бўлишини болаларга тушунтиради.

\section{"Рангли автомобиллар" ўйини}

Ўйиннинг мақсади: "Р" товушини нутқда хосил қилиш.

Ўйиннинг бориши: Болалар бир қатор бўлиб стулчаларда ўтирадилар. Улар автомобил хайдовчиларидир. Хар бир болага қоғоздан ясалган халқа, яъни машинанинг руллари берилади. Логопеднинг ёнида бир нечта рангли байроқчалар туради. Логопед байроқчани кўтарганда ўша рангдаги рул эгалари машиналарини хайдайдилар ва моторнинг овозига тақлид қилиб “p-p-p” деб талаффуз этадилар. Логопед байроқчани пастга туширганда машиналар тўхтайди ва болалар гаражга қайтадилар. Кейин логопед бошқа рангдаги байроқчани кўтаради. Ўйин шу тариқа давом этади. Адашган бола ўйиндан чиқади. Ғолиб бўлган болага машина совға қилинади.

“ўз расмингни топ" ўйини

ўйиннинг мақсади: “P”-“Л” товушларини фарқлашга ўргатиш.

Ўйиннинг бориши: Логопед болаларга "р" ва “л” товуши бор расмларни олиб тартиб билан қўйиб чиқади. Логопед болаларни 2-гурухга бўлади.1-гурух боалари "p" товуши бор бўлган расмларни олади, 2-гурух болалари эса "л" товуши бор бўлган расмларни олади. Логопедни кўрсатмаси билан хар бир гурухдан биттадан бола ўз товушига таъллуқли бўлган расмни олади. Сўнгра ўз гурухи олдига келиб, биринчи турган болани қўлига секин туртади ва болаларнинг орқасига бориб туради. Хамма болалар расмни олиб бўлганларидан кейин стулга ўтиришади. Хар бир бола ўз расмини кўрсатиб номини айтади. Масалан: ручка, ракета, лола, стол, стул, анор, рўмол олмохон, гилос, гул, олма, хўроз, тарвуз, карам, сигир. Қолган болалар эса ўртоғи расмни тўғри олганлиги ёки йўқлигини текшириб борадилар. Болалар расмни олганларидан сўнг уни номлаб, бўғинларга ажратадилар ва “р” ёки “л” товушлари сўзнинг бошида, ўртасида, охирида келганини айтадилар.

Хулоса қилиб шуни айтиш керакки, мактабгача таълим ёшидаги болаларнинг асосий фаолияти ўйин эканлиги барчага маълум, шунинг учун хам ўйин орқали олиб борилган барча фаолиятлар болаларга таълим-тарбия бериш жараёнларида, шунингдек, улар нутқида учрайдиган камчиликларни бартараф этишда мухим ахамият касб этади.

Фойдаланилган адабиётлар:

1. Мирзиёев Ш.М. “Қонун устуворлиги ва инсон манфаатларини таъминлаш - юрт тараққиёти ва халқ фаровонлиги гарови” мавзусидаги Ўзбекистон Республикаси Конституцияси қабул қилинганининг 24 йиллигига бағишланган тантанали маросимдаги маърузаси. - Т.: “Ўзбекистон”, 2017.

2. Мирзиёев Ш.М. Буюк келажагимизни мард ва олижаноб халқимиз билан бирга қурамиз. - Т.: “Ўзбекистон”, 20172

3. Ахмедова 3., Аюпова М., Хамидова М. Логопедик уйин. Тошкент2013.

4. М.Аюпова. Логопедия. Тошкент-2007.

5. К.Шодиева “Мактабгача ёшдаги болаларни тўғри талаффузга ўргатиш” Тошкент.1995.

6. Игры в логопедической работе с детьми. Под ред. В.И.Селиверства. Москва 1991.

7. И.Г. Веретенникова. Логопедическая работа с детьми дошкольного возроста. Тошкент - 1998. 9

(C) Д.А. Хомидова, 2019. 


\section{Юридические науки и государственное управление}

удк 340

\section{УЧАСТИЕ РЕСПУБЛИКИ УЗБЕКИСТАН В МЕЖДУНАРОДНОЙ ПРОГРАММЕ}

Х.М. Акрамов ${ }^{1}$

Аннотация

В данной статье рассмотрен вопрос участия республики Узбекистан в международной программе Сендайской рамочной программы по снижению риска бедствий на 2015-2030 гг. по охране окружающей среды и снижению риска различных бедствий.

Ключевые слова: Сендайская рамочная программа, экология, глобальные бедствия.

Правительство республики Узбекистан проводит планомерную и целенаправленную политику в области безопасности населения при чрезвычайных ситуациях. Подтверждением этого является постановление правительства «О мерах по реализации Сендайской рамочной программы по снижению риска бедствий на 2015-2030 г2. в республике Узбекистан» от 12 апреля 2019 года. [1]

Изходя из Сендайской рамочной программы по снижению риска бедствий на 2015-2030 г2., правительство Узбекистана приняло постановление, где детально указывается национальная Стратегия достижения целей на период с 2019 по 2030 годы.

Суть Сендайской рамочной программы по снижению риска бедствий на 2015-2030 г2. принятой на Третьей Всемирной конференции в Сендае (Япония) 18 марта 2015 г. является результатом консультаций с заинтересованными сторонами, начатых в марте 2012 г., и межправительственных переговоров, проходивших с июля 2014 г. по март 2015 г., при поддержке Бюро по сокращению риска бедствий ООН и по поручению Генеральной Ассамблеи ООН. [1]

Сендайская рамочная программа - это продолжение Хиогской рамочной программы действий (ХПД) на 2005-2015 гг. где было принято постановление по созданию потенциала противодействия бедствиям на уровне государств и общин. ХПД была разработана в целях придания дополнительного импульса процессу глобальной деятельности, предусмотренной Международными рамками действий по уменьшению опасности стихийных бедствий 1989 г. и Йокогамской стратегией по обеспечению более безопасного мира. Основными принципамиявляются: предотвращения стихийных бедствий, обеспечения готовности и смягчения их последствий, принятым в 1994 г.

Основа Сендайской рамочной программы- преемственность работы, проделанной государствами и другими заинтересованными сторонами в рамках ХПД, и ввод ряда новшеств, предусмотренных в ходе консультаций и переговоров. Многие специалисты определили наиболее значимые сдвиги, в том числе сильный акцент на управлении рисками бедствий в противовес ликвидации последствий бедствий, определение семи глобальных целей, снижение риска бедствий как ожидаемый результат, постановка цели, направленной на предотвращение новых рисков, снижение существующего риска и повышение устойчиво-

${ }^{1}$ Акрамов Хуснитдин Мухитдинович - кандидат педагогических наук, доцент кафедры методики преподавания профессионального образования, Наманганский государственный университет, Узбекистан. 
сти, а также ряд руководящих принципов, в том числе предусматривающих возложение на государства первоочередной ответственности за предупреждение и сокращение риска бедствий, участие в этом всех слоев общества и всех государственных учреждений. Кроме того, значительно расширен охват по уменьшению риска бедствий с целью сосредоточения внимания на природных опасных явлениях и техногенных угрозах, а также связанных с ними экологических, технологических и биологических угрозах и рисках. Повсеместно и настоятельно продвигается идея необходимости обеспечения устойчивости показателей здоровья.

Кроме того, в Сендайской рамочной программе сформулировано следующее: необходимость более глубокого понимания риска бедствий во всех его аспектах, связанных с характеристиками воздействия, уязвимости и опасности; укрепление систем управления рисками бедствий, в том числе национальных платформ; ответственность за управление рисками бедствий; готовность к восстановлению по принципу «лучше, чем было»; признание заинтересованных сторон и их ролей; мобилизация учитывающих риски инвестиций для предотвращения появления нового риска; устойчивость инфраструктуры здравоохранения, культурного наследия и рабочей среды; усиление международного сотрудничества и глобального партнерства, а также основанных на информации о рисках политики и программ доноров, в том числе финансовой поддержки и привлечения займов международных финансовых институтов.[2] В дополнение к этому, существует четкое осознание того, что Глобальная платформа по снижению риска бедствий и региональные платформы по снижению риска бедствий являются механизмами для согласования повестки дня, проведения мониторинга и периодического пересмотра, которые призваны оказать поддержку органам управления $\mathrm{OOH}$.

Перед UNISDR поставлена задача оказывать поддержку при реализации, проведении мониторинга выполнения и пересмотре Сендайской рамочной программы.

Сендайская рамочная программа по снижению риска бедствий на 20152030 годы состоит из 50 пунктов, где детально рассмотрены6 сфера охвата и предназначение, ожидаемый результат, цель и задачи.

Исходя из задач, которые заключаются в:

1-Существенное снижение глобальных показателей связанной с бедствиями к 2030 году;

2-Существенное снижение числа пострадавших людей по всему миру к 2030 году;

3-Сокращение прямого экономического ущерба, причиняемого бедствиями, по отношению к общемировому валовому внутреннему продукту (ВВП) к 2030 году;

4-Существенное уменьшение ущерба от бедствий в области критически важных объектов ифраструктуры и базовых услуг, включая медицинские и образовательные учреждения, путём повышения их устойчивости к 2030 году;

5-Существенное увеличение числа стран, имеющих национальные и местные стратегии снижения риска бедствий, к 2030 году;

6-Существенное увеличение международного сотрудничества в развивающих странах;

7-Существенное повышение доступности и доступа населения к системам раннего предупреждения о различных бедствиях, к информации о рисках бедствий и их оценкам к 2030 г. [2]

Были определены приоритетные направления действий это:

- понисание риска бедствий,

-укрепление систем управления риском бедствий в целях снижения риска бедствий,

-инвестиции в снижение риска бедствий для достижения устойчивости,

-повышение готовности к бедствиям в целях эффективного реагирования, а также восстановление, реабилитация и реконструкция по принципу «лучше, чем было».

А также ряд руководящих принципов по претворению Сендайской рамочной программы в жизнь. 
В программе национальной Стратегии, для претворения в жизнь Сендайской рамочной программы по снижению риска бедствий на 2015-2030 г2., достижении целей на 2018-2030 годы предусмотрено:

-совершенствование нормативно-правовой и методической базы в области уменьшения риска бедствий, охрана населения и территорий при чрезвычайных ситуациях;

-разработка и внедрение передовых технологий и инженерно-технических средств для предотвращения чрезвычайных бедствий;

-разработка и развитие систем прогнозирования и мониторинга чрезвычайных бедствий;

- организация, развитие и содержание в рабочем порядке систем руководства, связи и оповещения;

-разработка и развитие систем обеспечения жизнедеятельности населения, пострадавших от чрезвычайных бедствий;

- совершенствование системы подготовки специалистов (руководящий состав) и население к действиям в чрезвычайных ситуациях;

Из постановления правительства республики видно, что курс Узбекистана по охране жизнедеятельности населения при чрезвычайных ситуациях и безопасность является приоритетным в его политике.

Список литературы:

1. Сендайская рамочная программа по снижению риска бедствий на 20152030 гг. www.preventionweb.net/go/sfdrr

2. «2015-2030 йилларда офатлар хавфини камайтириш бўйича Сендай хадли дастури» ни Ўзбекистон республикасида амалга ошириш чора-тадбирлари тўғрисида.,Ўзбекистон республикаси вазирлар махкамасининг 299 сонли қарори. Тошкент 12 апрель 2019 йил. 
удк 340

\section{РОЛЬ ГОСУДАРСТВЕННОЙ МОЛОДЕЖНОЙ ПОЛИТИКИ}

В РАЗВИТИИ ОБЩЕСТВА

Д.А. Рахимбоева ${ }^{1}$

Аннотация

Государственная молодежная политика играет важную роль в воспитании подрастающего поколения в духовно соответствующем, духовно зрелом обществе.

Ключевые слова: сообщество, развитие, политика, молодежь, воспитание, поколение

Jonajon yurtimiz mustaqilligining 28 yilligini katta yutuqlar, ulkan zafarlar, ko`tarinki ruh, katta shijoat, ijod bilan kutib oldi.

Respublikamizdagi tinchlik, barqarorlik, osoyishtalik, turmush tarzimizdagi farovonlik, ertangi kunga ishonch, ayniqsa yoshlarimizning ruhiyatida, kayfiyatida, qarashlarida ijobiy o'zgarishlar yuksalib bormoqda.

Albatta, bu borada jamiyatimizning kichik lekin muhim bo lagi bo 'lmish oilada ham sezilmoqda.Oila-jamiyatning kichik, ammo muhim hujayrasidir, undagi sog'lom ijtimoiy muhit yosh avlodning ma naviy-axloqiy,huquqiy, siyosiy, g’oyaviy tarbiyasida muhim ahamiyatga ega, mustaqil yurtimizning kelajagi iastiqboli bu oilada kamol topayotgan farzandlarimiz tarbiyasidadir.Sharqda oila-oltin qo'rg’on hisoblangan va xisoblanib kelmoqda. Undagi yoshlar tarbiyasi esa shu qo 'rg onning asosiy maqsadi hisoblangan.Tarbiya borasidagi A.Avloniyning: "Agar bir kishi yoshligidan nafsi buzulib, tarbiyasiz, axloqsiz bo lib o`sdimi, Allohi Akbar, bunday kishilardan yaxshilik kutmak yerdan turib yulduzlarga qo`l uzatmak kabidir." ${ }^{2}$-deydi.

Jamiyatimiz rivojlanib, yildan-yilga takomillashib borishida yosh avlodni shu jamiyatga mos, xos ruhda tarbiyalashda yoshlarga oid davlat siyosatining ahamiyati kattadir.

Bu siyosatning mazmunini teran anglamoq barchamiz uchun muhimdir.Har bir oilada farzandlar-o`g'il qizlar, nabiralar,chevaralar kamol topmoqda.0`zbek oilasi uchun farzandlarning kamoli,jismonan, ma`nan, axloqan takomillashib borishi eng muhim, kechiktirib bo`lmaydigan dolzarb masalalardan biri hisoblangan. Oilaviy urfodatlarimizda, udum va marosimlarimizda bu masalalar o`z ifodasini topgan. Shunday ekan, yoshlarga oid olib borilayotgan jamiyatimiz siyosatining voqeligimizdagi eng muhim masalalardan biri sifatida qaramoq uning mag zini barcha anglamog $i$ va hissa qo`shmog`i lozim.Ma lumki oilada bola tarbiyasi bilan shug ullanish ko`proq ayollar zimmasiga tushadi, hozirgi vaziyat esa nozik, muhim masalaga erkaklar ham ma`sul bo'Isinlar. O'zbek oilalarida keksalar doimo hurmatda, e`zozda bo'lganlar.Bejizga xalqimiz "Qarisi bor uyning parisi bor", - deb aytmagan.Bobo va momolarimiz tinchlik va xotirjamlikni ulug laganlar, doimo xalqqa yoqadigan yaxshiliklar qilib, rahmat olib keladigan tarbiyani eng ulug' ne'matdir deb qaraganlar. Shuning uchun ham yosh avlodni komil inson ruhida tarbiyalashda bu qadriyatlardan foydalanmog imiz lozim.

Oilada farzandlar vaqtini taqsimlash muhim ahamiyatga ega hisoblangan.Ular maktabdan kelib uy ishlariga yordamlashganlar,ukalariga qarashgan, xonadonlarda hayvonlar bo 'lsa,unga yem berishgan, tagini tozalashgan,dasturxon atrofida o'tirishib kattalarning hikmatli gaplari va hayot tajribalari bilan o`rtoqlashganlar. Shunday ekan,bugungi yoshlarga oid siyosatlarning mazmun-mohiyatini tushuntirib,ularning inson, shaxs o'zligini anglashidagi rolini yoshlar ongiga singdirmoq lozim.Farzandlarimizning $0 ` z$ vaqtlarini qanday o`tkazayotganlarini nimalar bilan shug ullanayotganlari

\footnotetext{
${ }^{1}$ Рахимбоева Дилбар Абдихамитовна - к.ф.н.,доцент, Наманганский государственный университет, Узбекистан.
}

${ }^{2}$ A. Avloniy. Turkiy guliston yoxud axloq kitobi to'grisida. - T.:1993 yil 3-bet. 
qanday kitoblar o`qiyotganlarini,yon atroflaridagi do`st-birodarlari kim ekanligini nazorat qilish, ular qalbiga mehr orqali kirish muhimdir.

Bu borada qator tashviqot, tarbiyaviy ishlarni amalga oshirishda barcha birday ma`sul bo`lmog`i lozim.0`qituvchilar, oliy ta`lim professor o`qituvchilari,mahalla fuqarolar yig ini, ichki ishlar vakillari ishtirokida eng namunali oilalar, keksa-nuroniy faxriylarimiz hamkorligida olib borilishi kerak.

Bizga ma`lumki vatanimiz o’z taraqqiyotini yangi bosqichga qadam qo`ymoqda.Bu borada harakatlar strategiyasida belgilab berilgan. "Milliy tiklanishdan milliy yuksalish sari" degan ustuvor g`oya biz uchun dasturamal bo lib xizmat qilmoqda." ${ }^{1}$

Bu muhim tamoyil barchamizni ijodga, yuksalishga yetaklaydi.Har bir inson shu buyuk yurt uchun ona zamin uchun butun bilimi, shijoati, ilm-u tafakkurini sarflashga harakat qilmoqda.

Respublikamizda ijtimoiy rivojlanish bo`yicha o`ziga xos tizim shakllanmoqda. Masalan "Obod qishloq", "Obod mahalla","Yoshlar- kelajagimiz", "Besh ijobiy tashabbus" kabi dasturlar barchamizni fikrlashga ishlashga ijod qilishga undaydi.

Mamlakatimiz bo`ylab yoyilgan besh muhim tashabbusni misol qilib keltirishimiz mumkin va u quyidagilarni o`z ichiga oladi:

1. Birinchi tashabbus-farzandlarimizning musiqa, rassomlik, adabiyot, teatr va san`atga oshno qilishga qaratilgan.

2. Ikkinchi tashabbus-yoshlarni jismoniy tarbiya va madaniyat, sportga oshno qilish, har tomonlama sog lom avlodni kamolga yetkazish.

3. Uchinchi tashabbus-yoshlarning komputer va internetdan samarali foydalanishi.

4. To`rtinchi tashabbus-yoshlar ma`naviyatini yuksaltirish, ular o`rtasida kitobxonlikni keng targ ì qilish

5. Beshinchi tashabbus - xotin qizlarni ish bilan ta'minlash

Yuqorida qayd etilgan har bir tashabbus qimmatli, donishmandlarcha mazmunmohiyatga ega.U yoshlarni go zallikka oshno bo 'lishga undaydi.Shu bilan birga jismonan sog ’om va ko`rkam, ruhan tetik bo lishga chaqiradi.Ayniqsa jamiyatimizda xotinqizlarni ish bilan ta`minlashga chaqirishi ayollarni, qizlarimizni o`z kuch irodalariga ishonch, qadr-qimmatlarini,o zligini anglash imkonini beradi.Ushbu tashabbus yoshlarimizning kuchiga kuch,g ayratiga g ayrat ,ijodiga esa ijod qo `shib kelmoqda. Bunga javoban vatanimiz ravnaqi, istiqbolini qadrlab, tolmay o`qib, ishlab, yaratib, hech kimdan kam emasligimizni dunyoga isbot etayotgan avlodga egamiz!

Bizning avlod ruxiyatida buyuk qomusiylik xam dunyoviy xam diniy allomalarimizning qoni bor. Jumladan: sharq arastusi Farobiy shayx- ur-rais ibn Sino? Olimlarning raxbari A. Beruniy, M. Xorazmiy, al - Fargoniy va boshqalar o'z ta'limotlarida o'sha davrga xos bo'lgan barcha ilmlarda ijod qilganlar, bir necha tillarni mukammal bilganlari bois ko'p nodir asarlarni asl xolatida o'qiganlar taqrizlar yozganlar.

Sharq pedagogikasining qomusiy asari b o'lmish Qobusnomada ham axloqan kamol topishga kata e'tibor qaratilgan. Jumladan qator aforizmlar, pand-nasixatlar bayon etilgan.

Masalan:

-Xunarsiz kishi bilan do'stlik qilmag'il, nedin kim bunday kishi do'stlik va dushmanlikka loyiq emasdir.

-Xar kishining bilmi bo'lsa-yu ammo unga loyiq aqli bo'lmasa bu bilim zarar yetkargusidir. ${ }^{2}$

Bunday purma'no so'zlarni o'qish va o'rganish xozirgi zamon va davr talabidir, bunday qadriyatlarimiz yosh avlodni ma'naviy axloqiy jixatdan tarbiya topishda kata axamiyatga egadir.

${ }^{1}$ Mustaqillik darsi"Jonajon O'zbekiston mangu bo'l omon" T - 2019 yil 3-bet

${ }^{2}$ Qobusnoma. T.: O'qituvchi NMIU-2006 yil 57-58 betlar 


\section{Информация для авторов}

Журнал «Ученый XXI века» выходит ежемесячно.

К публикации принимаются статьи студентов и магистрантов, которые желают опубликовать результаты своего исследования и представить их своим коллегам.

В редакцию журнала предоставляются в отдельных файлах по электронной почте следующие материалы:

1. Авторский оригинал статьи (на русском языке) в формате Word (версия 1997-2007).

Текст набирается шрифтом Times New Roman Cyr, кеглем 14 pt, с полуторным междустрочным интервалом. Отступы в начале абзаца - 0, 7 см, абзацы четко обозначены. Поля (в см): слева и сверху - 2, справа и снизу 1,5 .

Структура текста:

- Сведения об авторе/авторах: имя, отчество, фамилия.

- Название статьи.

- Аннотация статьи (3-5 строчек).

- Ключевые слова по содержанию статьи (6-8 слов) размещаются после аннотации.

- Основной текст статьи.

Страницы не нумеруются!

Объем статьи - не ограничивается.

В названии файла необходимо указать фамилию, инициалы автора (первого соавтора). Например, Иванов И.В. статья.

Статья может содержать любое количество иллюстративного материала. Рисунки предоставляются в тексте статьи и обязательно в отдельном файле в формате TIFF/JPG разрешением не менее $300 \mathrm{dpi}$.

Под каждым рисунком обязательно должно быть название.

Весь иллюстративный материал выполняется оттенками черного и серого цветов.

Формулы выполняются во встроенном редакторе формул Microsoft Word.

2. Сведения об авторе (авторах) (заполняются на каждого из авторов и высылаются в одном файле):

- имя, отчество, фамилия (полностью),

- место работы (учебы), занимаемая должность,

- сфера научных интересов,

- адрес (с почтовым индексом), на который можно выслать авторский экземпляр журнала,

- адрес электронной почты,

- контактный телефон,

- название рубрики, в которую необходимо включить публикацию,

- необходимое количество экземпляров журнала.

В названии файла необходимо указать фамилию, инициалы автора (первого соавтора). Например, Иванов И.В. сведения.

Адрес для направления статей и сведений об авторе:

uch21vek@gmail.com

Мы ждем Ваших статей! Удачи! 